A study on WASH practices and under five (U5) morbidity pattern using remote sensing and geographical information system in Udupi Taluk.

A dissertation submitted in Fulfillment of the Requirement for the Award of Master of Public Health (MPH) Degree

Submitted by

Dr Yogish C B
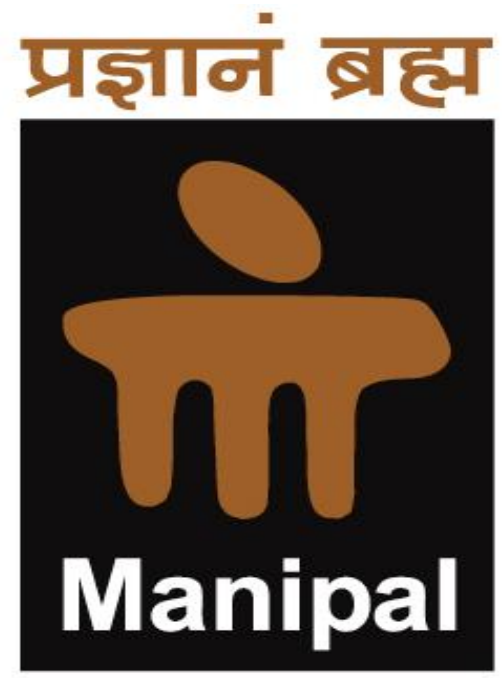

INSPIRED BY LIFE

\author{
DEPARTMENT OF PUBLIC HEALTH \\ MANIPAL UNIVERSITY, MANIPAL, INDIA \\ JULY 2015
}




\title{
A study on WASH practices and under five (U5) morbidity pattern using remote sensing and geographical information system in Udupi Taluk
}

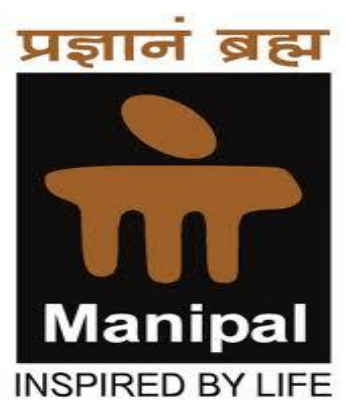

A Dissertation Submitted to Manipal University in Fulfillment for the Award of

\section{Master of Public Health (MPH) Degree}

\author{
By \\ Dr Yogish C B \\ Under the guidance of \\ Dr. Varalakshmi Chandra Sekaran \\ Lecture \\ Department of Public Health \\ Manipal University
}

\section{Co-guides}

Dr. Sanjay M Pattanshetty

Associate professor

Dept of Public Health

Manipal University

Manipal-576104
Dr.Jagadeesha Pai B

Associate professor

Dept of Civil Engineering

Manipal University

Manipal-576104
Dr. Shreemathi S Mayya

Associate professor

Dept of Bio- statistics

Manipal University

Manipal-576104 


\section{DECLARATION}

I hereby declare that the project entitled a study on "A study on WASH practices and under five (U5) morbidity pattern using remote sensing and geographical information system in Udupi Taluk" has been submitted during the year 2014 - 2015 under the valuable

guidance and supervision of Dr. Varalakshmi Chandra Sekaran, Lecturer, Department of Public Health, in fulfilment of the requirement of the Master of Public Health (MPH) degree of Manipal University. Further, I extend my declaration that this report is my original work and has previously not formed the basis for the award of any degree or diploma.

Date: 


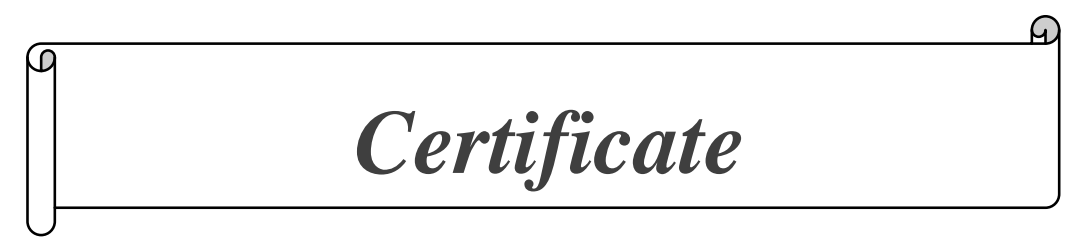

This is to certify that the Research Project entitled "A study on WASH practices and under five (U5) morbidity pattern using remote sensing and geographical information system in Udupi Taluk" prepared by Dr Yogish C B under my supervision in fulfilment of the requirement for Master of Public Health, Manipal University, has not previously formed the basis for the award of any degree or diploma by this or any other University and that this work is a record of the candidate's personal work.

Date:

Dr. Sanjay M Pattanshetty

Place: Associate professor Department of Public Health, Manipal University. 


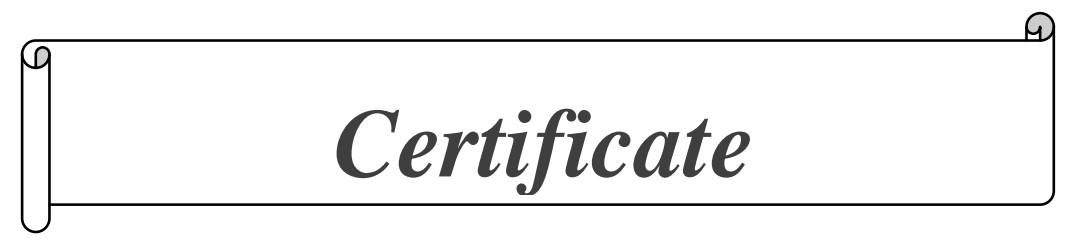

This is to certify that the dissertation entitled, "A study on WASH practices and under five (U5) morbidity pattern using remote sensing and geographical information system in Udupi Taluk" is a bona fide work done by Dr Yogish C B in the Department of Public Health, Manipal University, under our direct supervision and guidance.

\section{Guide}

Dr. Varalakshmi Chandra Sekaran

Lecturer

Department of Public Health

Manipal University

\section{Co-Guides:}

Co-guide Name

Dr. Sanjay M Pattanshetty

Associate professor

Dept of Public Health

Manipal University

Manipal-576104

Date:

\section{Co-guide Name}

Dr.Jagadeesha Pai B

Associate professor

Dept of Civil Engineering

Manipal University,

Manipal-576104

Date:

\section{Co-guide Name}

Dr. Shreemathi S Mayya

Associate professor

Dept of Bio- statistics

Manipal University,

Manipal-576104

Date: 


\section{Acknowledgement}

I would first like to thank the participants, both formal and informal, that have agreed to take part in this research, for their time and information that they have provided. I like to extend my thanks for those who have given consistent, guidance, advice and encouragement in my endeavour.

I am deeply indebted to my parents Mr. Channabasappa and Mrs. Gayathrei and my brother Vagish for their prayers, inspiration, guidelines and support, without whose blessings this dissertation would not have been possible. Cannot thank them enough.

I would like to express my sincere gratitude to my mentor and MPH coordinator Dr. Sanjay M Pattanshetty, for giving me an opportunity and support to undertake this project

My deep sense of indebtedness to Dr. Varalakshmi Chandra Sekaran, my guide for her indisipensable contribution, valuable suggestions at every step of this study. It has been a great privilege to do my study under her guidance.

I like extend my special thanks to Dr. Jagadeesh Pai, MIT. His guidance in RS and GIS helped me a lot and gave confidence to work independently and NITK Surathkal to grant me the permission to access the remote sensing software. I am also grateful to Dr. Sheemathi S. Mayya, my co- guide from Department of Statistics, for her valuable suggestions to carry out this project.

I would also like to thank my classmates, friends for the support.

Thank you 


\begin{tabular}{|c|l|c|}
\hline Serial no. & \multicolumn{1}{|c|}{ Contents } & Page no. \\
\hline 1. & Acknowledgement & 6 \\
\hline 2. & Abbreviations and acronyms & 8 \\
\hline 3. & List of the Tables & 9 \\
\hline 4. & List of the Figures & 10 \\
\hline 5. & Annexure & 11 \\
\hline 6. & Executive Summary & 12 \\
\hline 7. & Introduction & 15 \\
\hline 8. & Aims and Objectives & 19 \\
\hline 9. & Review of Literature & 21 \\
\hline 10. & Methodology & 26 \\
\hline 11. & Results and Discussion & 67 \\
\hline 12. & Summary & 69 \\
\hline 13. & Conclusion & 71 \\
\hline 14. & Limitations & 73 \\
\hline 15. & Recommendations & 79 \\
\hline 16. & References & \\
\hline 17. & Annexures & 75 \\
\hline & & \\
\hline
\end{tabular}




\section{Abbreviations and acronyms}

MDG- Millennium Developmental goals

U5- Under five

WASH- water, sanitation and hygiene

WHO- World Health Organization

WB- World Bank

HIV- Human immunodeficiency virus

UNICEF- United Nations Childers's Fund

DALY- Disability adjusted life year

NFHS- National Family Health Survey

NRHM- National Rural Health Mission

DLHS-District Level Household \& Facility survey

GIS- Geographic information system

RS- Remote sensing

PHC- Primary health Centre

CHC- Community Health Centre

UHC- Urban Health Centre

FPAI- Family Planning Association of India

MO- Medical Officer

MHW- Male Health worker

ARI- Acute respiratory tract infection

LRTI- Lower respiratory tract infection

SD- Standard deviation 


\section{List of tables}

\begin{tabular}{|c|c|c|}
\hline $\begin{array}{l}\text { Table } \\
\text { no. }\end{array}$ & Title & $\begin{array}{l}\text { Page } \\
\text { no. }\end{array}$ \\
\hline 1. & Socio- demographic profile of respondent & 36 \\
\hline 2. & $\begin{array}{l}\text { Distribution of environmental factors and living condition of } \\
\text { participants }\end{array}$ & 37 \\
\hline 3. & Distribution of children by age and gender & 38 \\
\hline 4. & Distribution of children with current illness & 38 \\
\hline 5. & Distribution of morbidity conditions among (U5) children & 39 \\
\hline 6. & $\begin{array}{l}\text { Treatment seeking behaviour and practice of mothers towards children } \\
\text { health }\end{array}$ & 40 \\
\hline 7. & Nutritional status of participant children & 41 \\
\hline 8. & Difference in nutritional status based on gender of the children & 43 \\
\hline 9. & Knowledge about causes of diarrhoea and ORS solution. & 44 \\
\hline 10. & $\begin{array}{l}\text { Knowledge of ORS among mother/ caregiver of children with } \\
\text { diarrhoea }\end{array}$ & 45 \\
\hline 11. & Sources of water and water treatment practise. & 46 \\
\hline 12. & Distribution of sanitary facility and practices & 49 \\
\hline 13. & Hygiene practices. & 50 \\
\hline 14. & Materials used for washing their hands & 51 \\
\hline 15. & Feeding habits and practices. & 52 \\
\hline 16. & Association of diarrhoea with WASH practices & 53 \\
\hline 17. & Association between ownership and diarrhoea of the property. & 54 \\
\hline 18. & Association between WASH and cough & 54 \\
\hline 19. & Association of fever with co-morbidities & 55 \\
\hline
\end{tabular}




\section{List of figures}

\begin{tabular}{|c|c|c|}
\hline $\begin{array}{l}\text { Figure } \\
\text { no. }\end{array}$ & Title & $\begin{array}{l}\text { Page } \\
\text { no. }\end{array}$ \\
\hline 1. & Udupi taluk map & 27 \\
\hline 2. & Water sanitation and hygiene system map & 33 \\
\hline 3. & Weight for age & 42 \\
\hline 4. & Length/ Height for age & 42 \\
\hline 5. & Weight for length & 43 \\
\hline 6. & Distribution of drinking water according to source & 48 \\
\hline 7. & Types of drinking water sources. & 48 \\
\hline 8. & Map showing distribution of diarrhoea cases in Udupi taluk & 56 \\
\hline 9. & Map showing distribution of Case cluster diarrhoea cases & 57 \\
\hline 10. & $\begin{array}{l}\text { Map showing distribution of unimproved drinking water source in } \\
\text { Udupi taluk }\end{array}$ & 58 \\
\hline 11. & Map showing distribution of fever cases in Udupi taluk & 59 \\
\hline 12. & Map showing distribution of cough cases in Udupi taluk. & 60 \\
\hline 13. & $\begin{array}{l}\text { Map showing distribution of lower respiratory tract infection in } \\
\text { Udupi taluk }\end{array}$ & 61 \\
\hline 14. & $\begin{array}{l}\text { Distribution of diarrhoea cases with geographical structure of Udupi } \\
\text { taluk }\end{array}$ & 62 \\
\hline 15. & Distribution of diarrhoea case with satellite image in Malpe Beach & 63 \\
\hline
\end{tabular}




\section{Annexure}

\begin{tabular}{|c|l|c|}
\hline $\begin{array}{c}\text { Annexure } \\
\text { no. }\end{array}$ & \multicolumn{1}{|c|}{ Title } & $\begin{array}{c}\text { Page } \\
\text { No }\end{array}$ \\
\hline 1. & Subject information sheet & 80 \\
\hline 2. & Informed consent form & 82 \\
\hline 3. & Questionnaire & 84 \\
\hline 4. & Institutional Ethical Clearance Certificate & 88 \\
\hline
\end{tabular}


Executive Summary

12 | P a g e 
Millennium development goals seven (MDG-7) emphasizes about environmental sustainability. Globally one in five habitually defecates in open and globally, about $13 \%$ of world population collects water from unprotected sources; most of the Asian cities fail to meet national water quality standards. MDG Goal-4 targets reducing child mortality. Under the age group of five years diarrhoea is the second biggest cause of death cause by poor water, sanitation and hygiene (WASH) practices. Worldwide unsafe water, inadequate sanitation or insufficient hygiene leads to $80 \%$ of diarrhoea.

India accounts to $60 \%$ of world's open defecation, only $31 \%$ of population use improved sanitation, in rural areas it's about $21 \%$. In India diarrhoea kills one child per minute. Diarrhoea and respiratory infection are the leading cause of deaths in India. Over $40 \%$ of the diarrhoea and $30 \%$ of the respiratory infection among children can be reduced, particularly by practicing hand wash with soap after contacted with excreta. An adequate water supply and basic sanitation are important elements of primary health care. This study is an attempt to fill the gap in understanding WASH practices and morbidity pattern among under five children in Udupi taluk.

The objective of the study was to assess the morbidity pattern and factors associated with it among U5 children, to identify water, sanitation and hygiene practices in the community and to map morbidity patterns of U5 children in relation to water sources. A cross sectional study was conducted in between February 2015 to June 2015 across Udupi taluk among 258 children between the age group of three to 59 months, mixed method study design approach was used.

Of the 258 children, $55.4 \%$ participants were female. Majority of the participants lived in nuclear families (64.7\%). The current illness of ARI was $7.5 \%$ followed by pneumonia $(4.7 \%)$ and diarrhoea (2.8\%). Prevalence of ARI over a period of three months was $76.4 \%$ followed by fever 56.2\% and diarrhoea (22.1\%). Most of the parents preferred private setting for treatment of their children. On assessing weight for age $16.5 \%$ children were underweight and $8.8 \%$ were thin on assessing weight for length. Boys were thinner compare to female. Most of the households used improved sources of drinking water (95.3\%) and adequate sanitary facilities $(89.5 \%)$. Among them $58.1 \%$ drew water from protected dug wells. For drinking purpose, $24 \%$ of participants travelled outside the premises to fetch water from improved source, and at household level $61.6 \%$ used adequate water treatment methods. A minimal number of participants practiced open defecation of about 5\%. Almost the participants washed their hands before feeding the child $(98.8 \%)$ and $56.1 \%$ used water and soap. Logistic regression showed children less than 2 year 
were 4.26 times more likely to suffer from diarrhoea compared to the age group of 2 to 5 years. Association of fever and cough showed statistical significance. Qualitative data showed cause of diarrhoea was mainly due to food poisoning, unhygienic food; eating food from outside food and the main organism was viral followed by bacteria. Fever and cough were due to cross infection. 
Introduction 
In 1923 Mahatma Gandhi quoted

"Sanitation is more important than political Independence"(1).

"If we do not keep our backyards clean our swaraj will have a foul stench" (2).

During the millennium summit of 2000 of the United Nations, all the United Nations member states committed to achieve the Millennium development goals (MDG) by 2015 MDG goal- 7 emphasizes about environmental sustainability. According to World health organization (WHO) "Sanitation generally refers to the provision of facilities and services for the safe disposal of human urine and faeces" (3). One in five habitually defecates in open globally and India accounts to $60 \%$ of world's open defecation ${ }^{(4)}$. In India Only $31 \%$ of population use improved sanitation, in rural areas about $21 \%$ use improved sanitation. Over $50 \%$, i.e. an estimated 594 million population defecates in the open. Only $6 \%$ of rural children under the age of five uses a toilet, while only $11 \%$ of families dispose the children stool safely. There is a high risk of microbial contamination with water and food. Globally about $13 \%$ of world population collects water from unprotected sources. Most of the Asian cities fail to meet national water quality standards ${ }^{(5,6)}$. Data from World Bank, 2012 report shows that in India about $93 \%$ population has access to drinking water from an improved source $^{(7),} 67 \%$ of households do not treat their drinking water even though it could be with chemically or bacterially contaminated. A Public health Association study shows only $30 \%$ wash their hand with soap before preparing food, $38 \%$ before eating and $53 \%$ after defecation (6).

MDG Goal-4 targets reducing child mortality. Human immunodeficiency virus (HIV), tuberculosis and malaria are the three diseases gaining more attention but Diarrhoea alone kills young children each year than all three combined ${ }^{(6)}$. Under the age group of five years diarrhoea is the second biggest cause of death cause by poor water sanitation and hygiene (WASH) practices. Worldwide unsafe water, inadequate sanitation or insufficient hygiene leads to $80 \%$ of diarrhoea, while $50 \%$ of the underweight or malnutrition is associated with repeated diarrhoea or intestinal nematode infections. Under the age of five, Diarrhoea alone takes away the life of 1.4 million children preventable death per year. United Nations Children's Fund (UNICEF) and WHO issued a report on 2009 highlighting another common cause of death among children were pneumonia (The forgotten Killer of children), with the same intent focus on diarrhoeal diseases, as central to improve child survival ${ }^{(8) .}$ Diarrhoea and respiratory infection are the leading cause of deaths in India. "In India diarrhoea kills one child per minute" ${ }^{(4)}$. Over $40 \%$ of the diarrhoea and $30 \%$ of the respiratory infection among 
children can be reduced, particularly by practicing hand wash with soap after contacted with excreta ${ }^{(9)}$. Good hand wash practices also shows reduction in almost $50 \%$ of diarrhoea, pneumonia, trachoma, scabies, skin and eye infection ${ }^{(10)}$. Hygiene promotion was the most cost effective intervention in the control of all the major diseases at US \$-5 per Disability Adjusted Life Year (DALY) averted. Increased use of safety water and hygiene helps in the reduction of morbidity malnutrition and intestinal helminthic infection leads to stunting, late entry to school and impaired cognitive function ${ }^{(5)}$. According to National Family Health Survey (NFHS-3) almost half the children U5 are stunt (48\%), 43\% are underweight ${ }^{(11)}$.

Adequate sanitation, hygiene and safe drinking water are the fundamental to the good health, by improving one or more of three components; reduction in the rates of morbidity and severity of various diseases particularly in children ${ }^{(12)}$. If everyone practices appropriate hygiene, safe drinking water and reliable sanitation, globally 2.4 million deaths (4.2\% of all deaths) can be preventable and $6.8 \%$ of DALY lost ${ }^{(5,6)}$.

Under National Rural Health Mission (NRHM) Village health, sanitation and Nutrition committee is the key element, this committee take collective action related to village level health and social determinants ${ }^{(13)}$. It involves the panchayati raj Institutions in the management of health system (VHSC 2014), it Provides water supply to each households, maintains sanitary level in the village and give subsidy to construct toilet facility ${ }^{(13) .}$

\section{Rationale}

An adequate water supply and basic sanitation are important elements of primary health care. A study was conducted on 2006 by World Bank on water and sanitation program estimated that "lack of sanitation coverage cost the country the equivalent of $6.4 \%$ of its 2006 gross domestic product" (4) and the report from the ministry of drinking water and sanitation shows, India spent over $\$ 3$ billion on constructing toilets across the country since 1986, In spite of such massive amounts invested India's sanitation campaign yield less results ${ }^{(14)}$. Diarrhoea, pneumonia and malnutrition are the leading causes of mortality and morbidity among children under age five worldwide; it is highly influenced by poor environment, socio economic condition of the family. Each year, an estimated 2.5 billion cases of diarrhoea occur among children under five years of age, and estimates suggest that overall incidence has remained relatively stable over the past two decades ${ }^{(8)}$. 
Though the indicator of Udupi taluk is fairly good; morbidity among under five remains challenging. Report of District Level Household \& Facility survey (DLHS) three from 20062007 shows that the population using piped drinking water was $27 \%, 76.9 \%$ had toilet facility and $54 \%$ population fall below poverty line ${ }^{(15)}$. Jalan $\mathrm{J}$ et al, conducted a study in 2003 shows prevalence of diarrhoea can be reduced by providing households with piped water ${ }^{(16)}$. Mothers and primary care givers are directly linked with the children's health.

Accurate information on WASH practices is not available to the stakeholders, national leaders, decision makers. Evidence based information can be used in various ways like assessment of progress towards MDG, promoted increase investment in the sector, focus attention on needy areas ${ }^{(17)}$. By current progress rate in sanitation it is of the most inaccessible target ${ }^{(4)}$. This study is an attempt to fill the gap in understanding WASH practices and morbidity pattern among under five children in Udupi taluk. This study assessed morbidity pattern and WASH practices using Geographic information system (GIS) and Remote sensing(RS) as GIS is an extraction of statistical analyses that join epidemiological, sociological, clinical and economic data with reference to space, it helps in understanding the human interact with their environment, disparities in the health outcomes with in a community ${ }^{(18)}$ 
Aim and Objectives 


\section{Aim}

To study the patterns of under five (U5) morbidity in relation with WASH practices using remote sensing and GIS in Udupi taluk

\section{Objectives}

1. To identify the morbidity pattern among U5 children

2. To identify water, sanitation and hygiene practices in the community

3. To find factors associated with morbidity among under five children

4. To map morbidity patterns of U5 children in relation to water sources 
Review of Literature 


\section{$\underline{\text { International }}$}

Bhandari T U et al $2013^{(19)}$

A cross sectional study was conducted in Kapilvastu District of Nepal, to assess the nutritional status of under five children. Children's weight for age shows $25 \%$ were below -3 standard deviation (SD), 30.8\% were below -2 SD and study shows stunting and underweight was seen in both the genders. Children's are more likely to suffer from diarrhoea, which had severed to moderate malnutrition in their childhood. Study result showed for better immunological status nutrition plays an important role.

Agustina R et al $2013^{(20)}$

A cross sectional study was conducted among low socioeconomic urban areas of east Jakarta. Seven days of prevalence of diarrhoea was assessed, food hygiene practices, food preparation, water source and safe drinking water, child's bottle feeding hygiene and housing $\&$ environmental condition were collected from the mother and care givers. Children's living less dirty sewage had low prevalence diarrhoea and mother food hygiene practices not affected on occurance of diarrhoea.

Tarique M D et al $2012^{(21)}$

It is an interventional study (SHEWA-B) was conducted in the Bangladesh targeted 68 sub district in 19 district. Aim to improve sanitation; hygiene and water supply and to assess SHEWA-B project effectiveness on changing behaviour and bringing down the diarrhoea and respiratory disease among under five children. The intervention results were found to be, improve child health many available, affordable and effective interventions are linked due to difficulties in scaling up it not reach the children. Difficulty in scaling up include weakness in the delivery system, inappropriate delivery strategies, limited resources, short time frame for planning, difficulties in estimating resources.

Goswami N D et al $2012^{(22)}$

A prospective cross sectional study was done in United States to determine case detection and feasibility community Tuberculosis screenin. GIS helps in better understand transmission 
dynamics of syphilis,HIV, And TB. The Yeild of a GIS based approach to TB screening was higher caopmared to traditional screening methods

\section{Bartram, j,et al $2010^{(23)}$}

This is the introductory article on water and sanitation from the Plos Medicine series. Globally $4.2 \%$ of death can be preventable by following appropriate, hygiene, reliable sanitation and drinking water. In developing countries diarrhoea, malnutrition and other diseases attributable to malnutrition, by practicing good WASH practices we can also endemic diarrhoea, intestinal helmintiasis, giardiasis, schistosomiasis, trachoma, thphoid, cholera, and cryptosporidiosis. $13 \%$ of the population lives where the water is collected from the far and unprotected source. By increase use of hygiene example from hand wash with soap we can prevent neonatal morbidity.

Pruss- ustun, A. et al (2002) ${ }^{(6)}$

On 2008 WHO Geneva has published safe water, better health. By ensuring personal, Domestic and community Hygiene will improve the quality of millions of individuals. Vector born diseases can be reduced by better managing water resources. It has an extensive direct and indirect economic benefit from micro level of house hold to the macro- perspective of national economics. By clear understanding the burden of diseases and clear understanding of alternative approaches to reduce the burden by providing the basic development strategy.

Hoque B A et al (1996) ${ }^{(24)}$

An intervention study was run by International Centre for Diarrhoeal Disease Research, Bangladesh for the period of 5 years (1983-87) about education on water supply, sanitation, hygine (wsh). After follow up of five years $82 \%$ of pumps were still working, $64 \%$ of latrine were in working condition. An about $84 \%$ adults were continuously using sanitary facility and knowledge about transmission of diseases were poor. 


\section{Indian studies}

Sumeet, R. et al (2014) ${ }^{(25)}$

Study was conducted in Madhya Pradesh, to measure the effect the total sanitation campaign (TSC) which is supported by the World Bank. They used cluster randomised control sampling technique in 80 rural villages. The intervention shows that improved sanitation facilities as defined by the WHO/ UNICEF, But it fails to show improved improve child health measures in terms of multiple health out comes

Myles Elledge, et al (2013) ${ }^{(4)}$

The united nation millennium development goals seven tells about environmental sustainability but it is most in accessible to achieve $75 \%$ of improved sanitation coverage by 2015. Globally 1.5 million children die from diarrheal disease and in India diarrhoea takes away one child per minute. World $60 \%$ of defecation happens only in India. World Bank study shows that India's lack of sanitation coverage cost the country the equivalent of $6.4 \%$ of its 2006 gross domestic product.

Singh N K et al (2013) ${ }^{(26)}$

A cross sectional study was done on Manipura to assess the morbidity among U5. Study shows commonly seen illness was respiratory infection with an episode of $2.6 \%$ per month followed by diarrhoea, an about $92.3 \%$ children suffered from ill in last 3 months.79.8\% children showed normal nutritional status.

Clasen T et al (2012) ${ }^{(27)}$

A cluster randomized trial with villages as the unit of randomization was done on Puri, Orissa. Outcome measurement was done on diarrhoea among U5 children, helminth infections, water quality, no of insect vectors, faecal pathogens in environment and cost and cost effective analysis also done. Delays in intervention roll-out caused logistical problems for planning of health outcome follow-up surveys. 


\section{Ramachandra P et al (2009) ${ }^{(28)}$}

A study was done by the Ramavhandra and Gopalan from the NFHS-3 database, to know the association of risk of under nutrition among preschool childrens. The study shows risk of morbidity was seen more among children's with lower BMI and wasting compared to stunting and underweight. Children are suffering from stunting and wasting has high risk of morbidity.

\section{Ansari, M A et al (2008) ${ }^{(29)}$}

A study was done to know the demographic profile and distribution pattern of diseases among under five in rural areas of Aligarh, the result shows that diarrhoea and acute respiratory tract infection seems to be more common among children. Skin infection and worm infection were more seen in 4 to 5 years of children.

Jalan J et al (2003) ${ }^{(16)}$

A study was done by using the house hold data from India's National Council of Applied Economic Research in 1993-94. Prospective score matching was done to assess the casual effect of child health on piped water in a cross sectional sample without replacement was used. The prevalence of diarrhoea was low in who had piped water than observationally identical households without it. This study pi pass education of mothers, poor families. 


\section{Methodology}


This chapter describes the methodology used to study the research problem i.e. Patterns of under five (U5) morbidity in relation with water, sanitation and hygiene (WASH) and possible associated factors for it in Udupi taluk.

The chapter will provide insight into the design of the study, study setting, study population, sampling technique, data collection procedures and ethical considerations. Furthermore, the analytical methods used to analyze the data will be discussed.

\section{Study design}

A cross sectional study was conducted using mixed method with quantitative and qualitative components of exploratory and explanatory design.

\section{Study Setting}

Udupi district is positioned in the southwest part of Karnataka. It consists of three taluks, Udupi, Karkala and Kundapura. Data from the 2011 census shows Udupi district has the population of $1,177,361$ of which males were 562,131 and females were 615,230, with the density of 329 people per sq km. In 2011 average literacy rate of Udupi was $86.24 \%{ }^{(30)}$.

Figure 1: Udupi taluk map

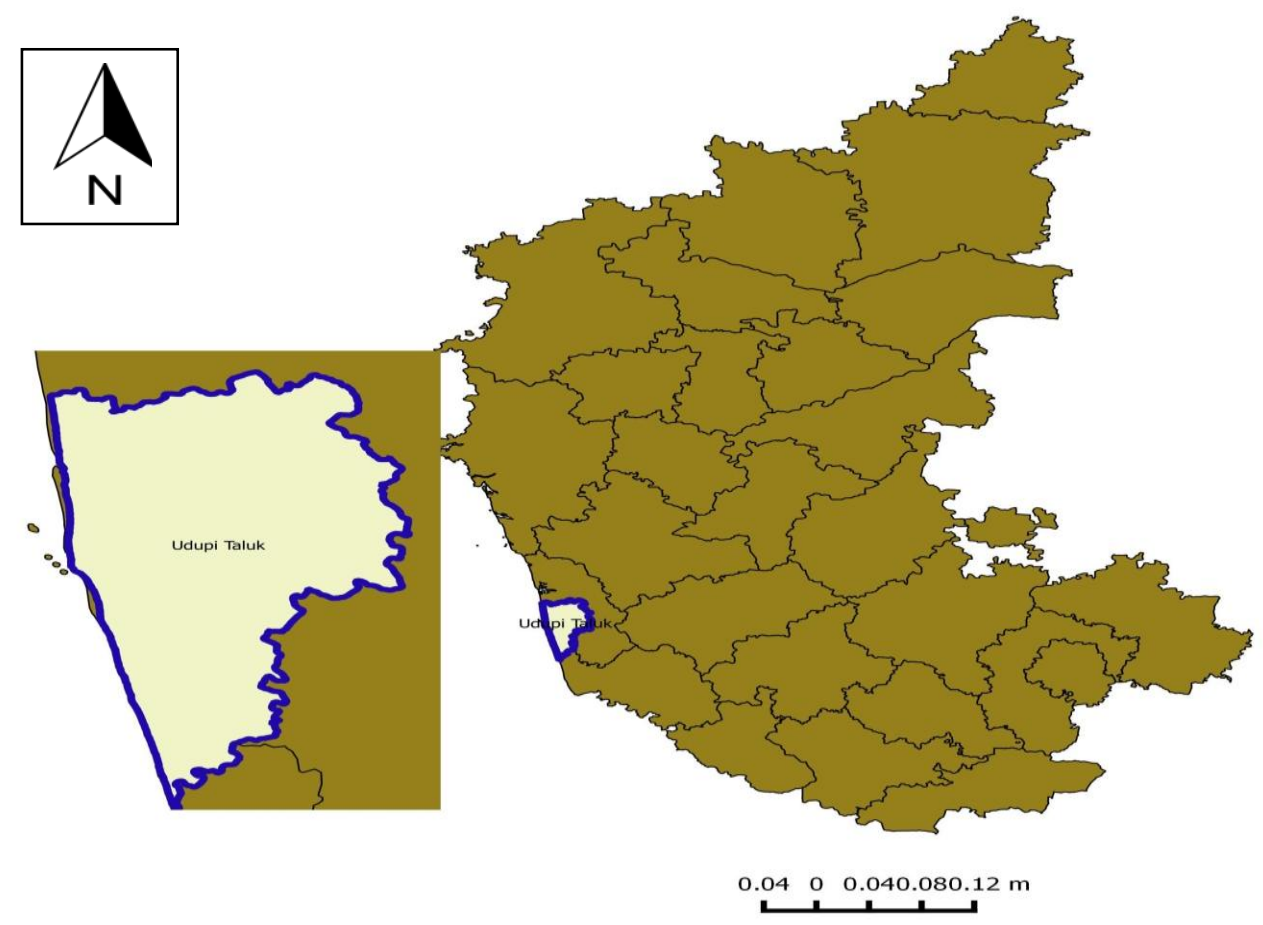




\section{Study Duration}

This study was conducted between February 2015 to July 2015 after obtaining permission from the Institutional Ethical Committee of Manipal University. (IEC 41/2015)

\section{Ethical consideration}

Ethical approval for the study was obtained by the Institutional Ethics Committee of Kasturaba Medical College, Manipal (IEC 41/2015) .Participants were provided with written information and oral Information on the study objectives, purpose of the study, risks \& benefits involved in the study, their rights to enter and cancel their participation at any time, during the study. Informed consent both for participation and for recording of the sessions was obtained from all participants. The informed consent was prepared according to the WHO guidelines for a parental consent in case of children below the age of 18 years. For convenience of the participants/ respondents the informed consent was mentioned in the local language of the area (Kannada). The study was only proceeded with once the respondent understood the study and gave written or oral consent. Every interview was given a unique code and the use of participant name or other identification details was discouraged to ensure the confidentiality.

\section{Operational definitions}

Diarrhoea: Diarrhoea is defined as the passage of three or more loose or liquid stools per day (or more frequent passage than is normal for the individual). Frequent passing of formed stools is not diarrhoea, nor is the passing of loose, "pasty" stools by breastfed babies ${ }^{(17)}$

Improved sanitation facilities/ Adequate Sanitation facility: Hygienically separates human excreta from human contact ${ }^{(17)}$.

It includes a flush/pour-flush toilet or latrine that flushes to a sewer, septic tank or pit. A ventilated improved pit (VIP) latrine, pit latrines with the pit well covered by a slab, or composting toilets are also considered improved ${ }^{(17)}$..

Types of sanitation facilities that are not likely to meet the criterion are: flush/pour flush elsewhere; pit latrine without a slab/open pit; bucket; and a hanging toilet ${ }^{(17)}$..

Improved water source: A piped water supply into the dwelling; piped water to a yard/plot; a public tap/standpipe; a tube well/borehole; a protected dug well; a protected spring; and rainwater $^{(17)}$.. 
Unimproved water source: An unprotected dug well; an unprotected spring; a cart with a small tank/drum; a water tanker-truck; and surface water ${ }^{(17)}$

\section{Quantitative component}

\section{Study population}

Mother or care givers and under five (U5) children (3 months to 59 months)

\section{Inclusion and exclusion criteria}

\section{Inclusion criteria:}

Mother or primary caregivers of under five children registered in the government health sector and in Anganwadi centers.

\section{Exclusion criteria:}

Parents of children who are not willing to take part in the study.

Severely ill child

\section{Sampling technique}

- $\quad$ Proportionate Stratified random sampling

\section{Sample size estimation}

$\mathrm{N}=\frac{(\mathrm{Z})^{2} * \mathrm{P}(1-\mathrm{P})}{(\mathrm{d})^{2}}$

Where $\mathrm{Z}=$ Value at specified confidential interval

$\mathrm{P}=18 \% \sim 20 \%$ from previous studies

$\mathrm{D}=0.05$ margin of error/ absolute precision

With confidential interval of $95 \%$

$\mathrm{N}=\underline{(1.96)^{2} * 0.20 * 0.80}$

$$
(0.05)^{2}
$$

$\mathrm{N}=246$

Therefore sample is 246

By adding 10\% non response rate the total sample size comes $273 \sim 280$ 


\section{Study tools}

1. Semi structured questionnaire which was piloted and validated by the experts. The questionnaire was in English and then it translated to local language Kannada.

Information was collected from the mothers/ primary caregivers on sociodemographic details, water sanitation and hygiene practice, morbidity history of the child in past three months, sanitation and hygiene practices, treatment seeking behavior.

2. Physical examination was done on the sampled children to identify current illness, by conducting general physical examination.

3. Mapping was done with the help of GIS.

\section{Data collection method}

Primary data was collected by principal investigator.

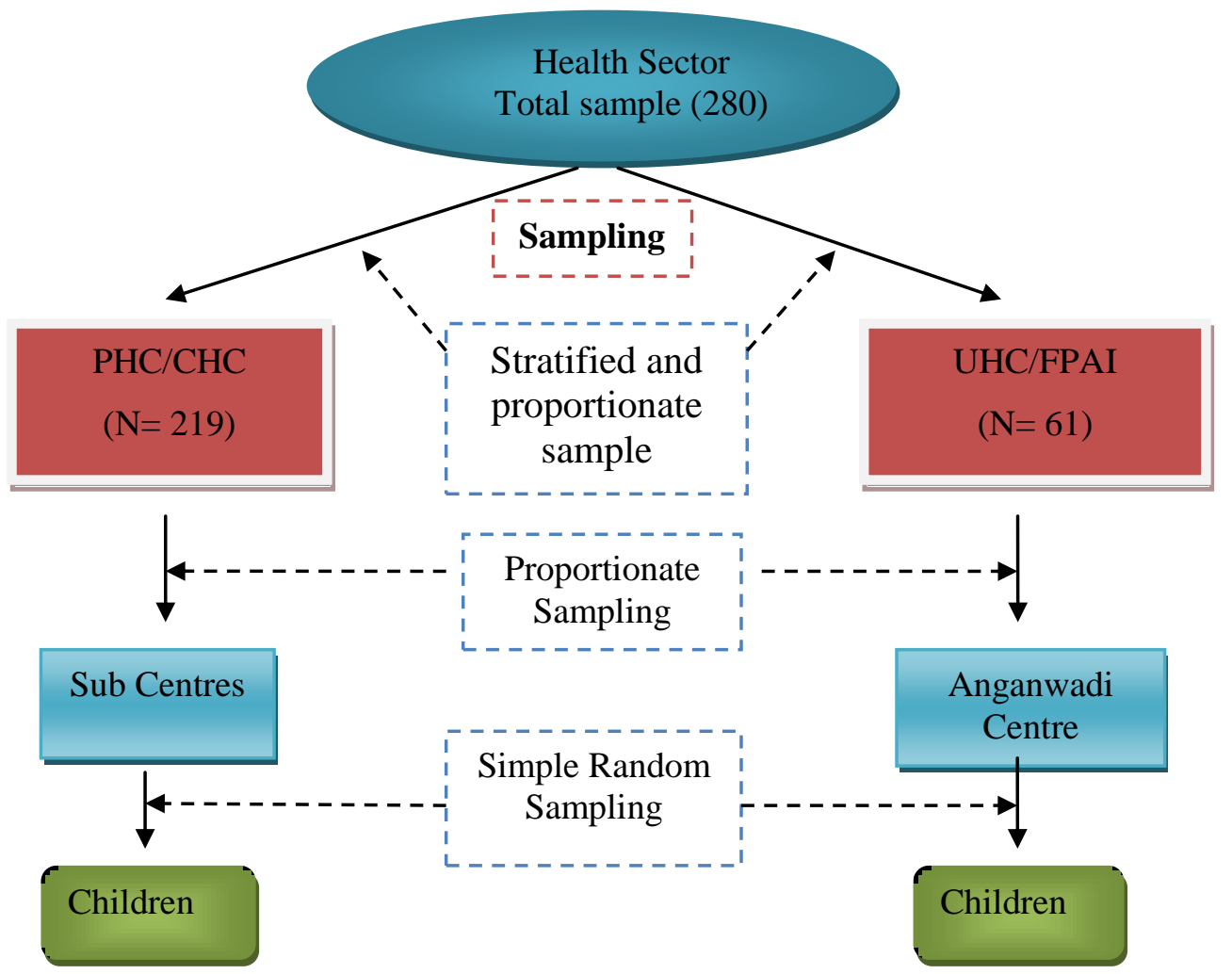

From the Udupi taluk health office, list of the health centers were obtained. The polio surveillance report of January 2015 was used to identify children under each Primary Health 
Center (PHC)/ Community Health Center (CHC) and Urban health Center (UHC)/ Family Planning Association of India (FPAI).

Selection of Children:

The health sector was stratified into PHC and CHC and into UHC/FPAI. This was further proportionately sampled and simple random sampling was done to sample children from subcenters and anganwadi centers

\section{Anthropometry}

Anthropometic measurements namely weight and heights of the children were recorded. Height was measured using tape with $0.1 \mathrm{~cm}$ precision. It was recorded by making the child stand next to a wall without shoes and then marked the corresponding measurement on the tape to the wall; this marked measurement was taken as the height of the child. For child below 1 year of age or child unable to stand, length was recorded in the place of height, by making the baby lying on the floor line was drawn perpendicular to head and to tip of the leg and length in between the lines was measured. Weight (in $\mathrm{kg}$ ) of the children was recorded using digital weighing scale, which was validated before the commencement of the study. Weight of the children of less than one year who were unable to stand was recorded as per WHO criteria. For these children weight of the mother was first recorded with the child and then without the child. Difference in between the two weights was taken as the weight of the child.

\section{Qualitative component:}

Thirteen in-depth interviews were conducted with mother or primary care givers of U5 children (3 months to 59 months) and stake holders including community leaders, PHC medical officer, private practitioners, grass root health workers and social worker. Most interviews lasted approximately 15 minutes. Interviews were held at the participant's house or at the participant's work place. All the interviews were performed by the principal investigator. In all, seven interviews were audio recorded using a voice recorder and notes were taken for six interviews. 


\section{Study tool}

A qualitative in-depth interview guide was developed with the result findings of qualitative and GIS data. Reason for the findings and community WASH practices were asked.

\section{Positionality:}

Positionality was maintained by wearing simple local traditional dress and by maintaining good rapport with the participant. While collecting the data, position level was maintained according the situation.

\section{Data Entry and transcription}

To maintain better quality of data, quantitative data was coded and entered and qualitative data has been transcribed on the same or following day from the data collection date. Qualitative data was first transcribed in to local language and later it has been translated to English by the Principal investigator.

\section{Data analysis}

Data was analyzed using statistical software SPSS version 15, Epi info version 7, WHO Anthro, remote sensing software ERDAS image 8.5, GIS software Q GIS version 2.6. Descriptive statistics, frequency and proportion were reported. Chi square and logistic regression was used to test the significance of association factors and qualitative data was analyses manually. 
Figure 2: Water sanitation and hygiene system map

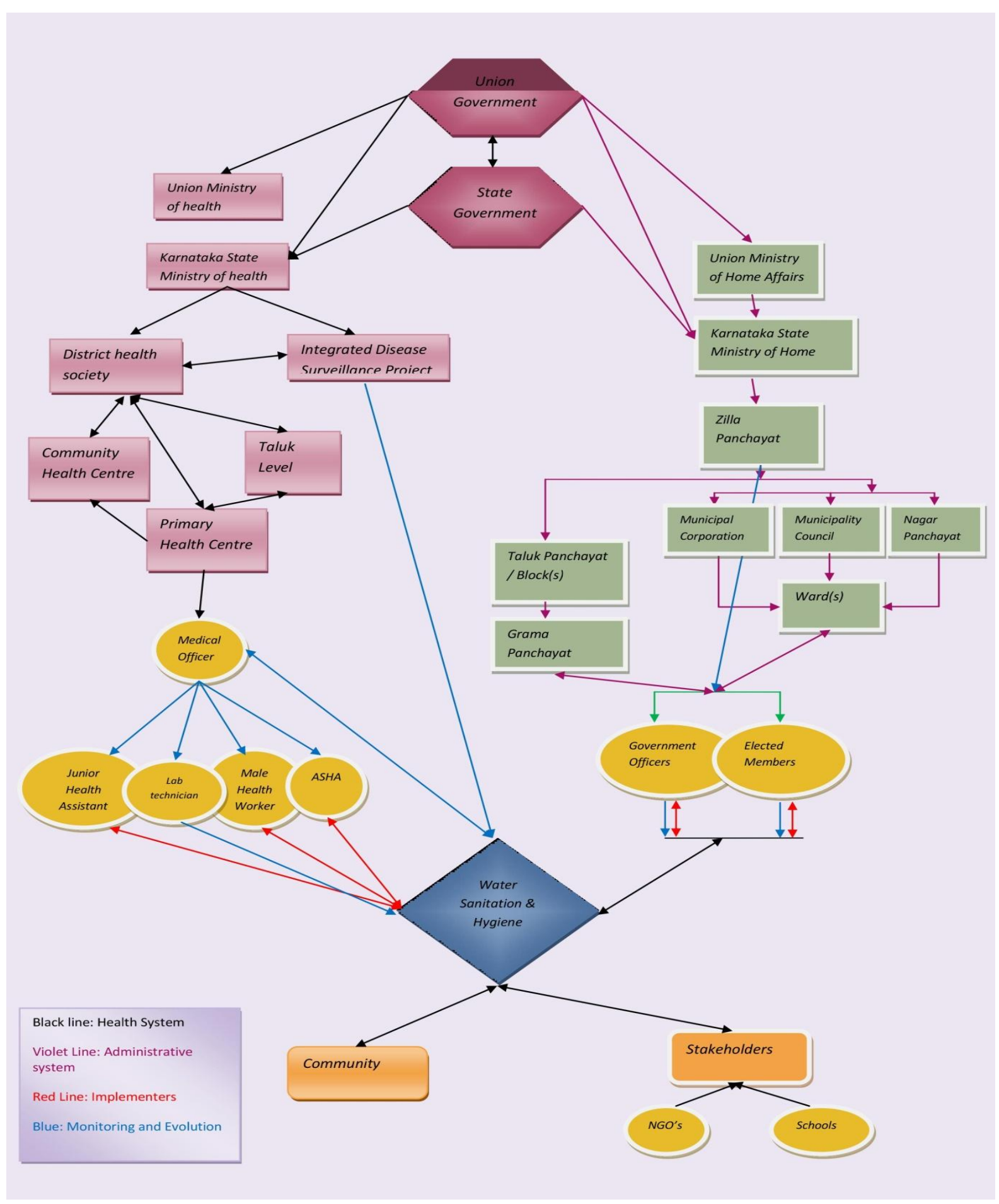


The Union Government of India lies atop the system map. They work in collaboration with the State Government of Karnataka to provide healthcare services to the population. The State Government of Karnataka can be further divided into the State Ministry of Health and State Ministry of Home Affairs, which are responsible for the provision of healthcare to the population of Karnataka.

The Karnataka State Ministry of Health is responsible for implementing the Program through District Health Society and Integrated Disease Surveillance Project, which is a horizontal program. The District Health Society is subdivided into the Community Health Center, the Taluk, and the Primary Health Center (PHC). At the PHC, the Medical Officer (MO) is the main coordinator who monitors and evaluates the development and implementation of healthcare programs. Under the MO, there are numerous stakeholders including: Junior Health Assistant, Lab Technician, Male Health Workers (MHWs), and Accredited Social Health Activists (ASHA). These implementers work very closely with one another in the completion of their respective roles, therefore they overlap within the system map. Out of these employees, the Junior Health Assistant, MHWs, and ASHAs are the grass root level implementers of the WASH program.

On the right side of the system map, the Karnataka State Ministry of Home Affairs leads into the Zilla Panchayat, which is responsible for Panchayat and Municipality systems. Under Zilla Panchayat there is a Taluk Panchayat, which is followed by Grama Panchayat. The Zilla Panchayat also controls numerous municipalities, which include: Municipal Corporation, Municipality Council, and Nagar Panchayat. Members are elected to work into the Grama Panchayat and Wards. The Government Officers implement and evaluate the effectiveness of WASH programs. Under WASH programs communities and stakeholders (e.g. NGOs and Schools) are directly involved. It is of note that within our system map it was difficult to illustrate the strengths of each relationship. This is due to the fact that we interviewed various stakeholders within different communities, all with their own distinct relationships to one another. Please refer to Annex A for a complete visual representation of the systems map. 
Results and Discussion 
The result and discussion section illustrates the research results after following statistical analysis. Tables, figures and comparison of the previous study findings are presented.

In the study, a total of 258 participants including children between three month to 59 months and mothers/ primary care givers were included to gather information on morbidity pattern and water sanitation and hygiene practice, factors associated with WASH and U5 morbidity and to map those finding using RS \& GIS. Information was obtained from mothers/ caregivers with the help of a semi structured about socio-demographic details, water sanitation and hygiene practice, morbidity history of the child in past 3 months, behavioral habits, treatment seeking behavior of children. The results have been presented according to the socio-demographic profile of the study population, morbidity pattern and cross tabulation of selected factors with morbidity condition. Chi square test to assess the association of selected factors with morbidity conditions and mapping the morbidity, Water source were done.

Table 1: Socio- demographic profile of respondent $(n=258)$

\begin{tabular}{|c|c|c|}
\hline Variable & Category & $\mathrm{n}=258(\%)$ \\
\hline \multirow{2}{*}{ Age of the children } & $<2$ years & $121(46.9 \%)$ \\
\hline & $=>2$ Years & $137(53.1 \%)$ \\
\hline \multirow{2}{*}{ Gender of the children } & Male & $115(46.6 \%)$ \\
\hline & Female & $143(55.4 \%)$ \\
\hline \multirow{3}{*}{$\begin{array}{l}\text { Religion of the mother/ } \\
\text { primary caregiver }\end{array}$} & Hindu & $217(84.1 \%)$ \\
\hline & Muslim & $27(10.5 \%)$ \\
\hline & Christian & $14(5.4 \%)$ \\
\hline \multirow{6}{*}{$\begin{array}{l}\text { Education of the mother/ } \\
\text { primary care giver }\end{array}$} & Never gone to school & $14(5.4 \%)$ \\
\hline & Up to Primary & $27(10.5 \%)$ \\
\hline & Middle School & $20(7.8 \%)$ \\
\hline & High School & $103(39.9 \%)$ \\
\hline & Pre-University & $48(18.6 \%)$ \\
\hline & Degree & $46(17.8 \%)$ \\
\hline
\end{tabular}


Table 1 shows the distribution of socio demographic details of the respondent.

The range of the age group of children was from three months to 59 months. Median age was 28 months with IQR $(12,42)$. Gender distribution showed that $55.4 \%$ of children were female. The majority were belongs to Hindu religion (84.1\%) followed by Muslim $(10.5 \%)$ and Christian (5.4\%). Literacy rate of mother was $94.6 \%$ out of whom $39.9 \%$ had high school education while middle school was at $(7.8 \%)$.

Table 2: Distribution of environmental factors and living condition of participants

\begin{tabular}{|c|c|c|}
\hline Variables & Category & $\mathrm{n}=258(\%)$ \\
\hline \multirow{3}{*}{ Type of family } & Nuclear & $167(64.7 \%)$ \\
\hline & Single & $87(33.7 \%)$ \\
\hline & Joint & $4(1.6 \%)$ \\
\hline \multirow{2}{*}{ Type of living house } & Pucca & $253(98.1 \%)$ \\
\hline & Kutcha & $5(1.9 \%)$ \\
\hline \multirow{4}{*}{ Ownership of the house } & Own & $216(83.7 \%)$ \\
\hline & Rented & $36(14 \%)$ \\
\hline & lease & $3(1.2 \%)$ \\
\hline & Free & $3(1.2 \%)$ \\
\hline \multirow{2}{*}{$\begin{array}{l}\text { Own Pets / Livestock / } \\
\text { cattle's }\end{array}$} & Yes & $131(50.8 \%)$ \\
\hline & No & $127(49.2 \%)$ \\
\hline
\end{tabular}

Table 2 shows the environmental factor and living condition of the participants.

Majority of the families lived in nuclear families (64.7\%). About $98.1 \%$ respondent living in a pucca housing. Out of 258 participants $83.7 \%$ spouse or they themselves own their homes. Half of the households (50.8\%) owned pets/ livestock/ cattle's. 
Table 3: Distribution of children by age and gender

\begin{tabular}{|c|c|c|c|}
\hline Age (Months) & $\begin{array}{l}\text { Male } \\
\mathrm{n}(\%)\end{array}$ & $\begin{array}{c}\text { Female } \\
\mathrm{n}(\%)\end{array}$ & $\begin{array}{l}\text { Total } \\
\mathrm{n}(\%)\end{array}$ \\
\hline 3-24 Months & $54(47 \%)$ & $67(46.9 \%)$ & $121(46.9 \%)$ \\
\hline 24-59 Months & $61(53 \%)$ & $76(53.1 \%)$ & $137(53.1 \%)$ \\
\hline Total & $115(100 \%)$ & $143(100 \%)$ & $258(100 \%)$ \\
\hline
\end{tabular}

The above table describes age and gender distribution with more than half $53.1 \%$ belongs to 24 to59 months comprising of 61(53\%) male and 76(53.1\%) female.

Table 4: Distribution of children with current illness

\begin{tabular}{|c|c|}
\hline Variable & $\begin{array}{c}\text { Incidence } \\
\mathrm{n}=254(\%)\end{array}$ \\
\hline Diarrhoea & $7(2.8 \%)$ \\
\hline Pneumonia & $12(4.7 \%)$ \\
\hline Fever & $2(0.8 \%)$ \\
\hline $\begin{array}{c}\text { Acute respiratory tract } \\
\text { infection (ARI) }\end{array}$ & $19(7.5 \%)$ \\
\hline Worm infestation & $11(4.3 \%)$ \\
\hline other & $8(3.15)$ \\
\hline
\end{tabular}

Table 4 explains about distribution of children's current illness. About $76.4 \%$ of children were healthy, ARI was found in $7.6 \%$ children followed by pneumonia (4.7\%) (This has been cross verified with medical prescription by the doctor). Other disease $(3.15 \%)$ includes cardiac disease, injuries and measles. 
Table 5: Distribution of morbidity conditions among (U5) children ( $n=258)$

\begin{tabular}{|c|c|c|}
\hline Variable & $\begin{array}{c}\text { Prevalence } \\
n=258(\%) \\
\text { over three months }\end{array}$ & $\begin{array}{l}\text { Frequency of disease } \\
\text { For } 3 \text { months }\end{array}$ \\
\hline \multirow{3}{*}{ Diarrhoea } & \multirow{3}{*}{$57(22.1 \%)$} & One episode: $48(84.2 \%)$ \\
\hline & & Two episodes: $8(14.0 \%)$ \\
\hline & & Three episodes: $1(1.8 \%)$ \\
\hline \multirow{4}{*}{ Fever } & \multirow{4}{*}{$145(56.2 \%)$} & One episode: $108(74.5 \%)$ \\
\hline & & Two episodes: $27(18.6 \%)$ \\
\hline & & Three episodes: $8(5.5 \%)$ \\
\hline & & Four episodes: $2(1.4 \%)$ \\
\hline \multirow{4}{*}{$\begin{array}{l}\text { Cough/ difficulty in } \\
\text { breathing }\end{array}$} & \multirow{4}{*}{$147(57.0 \%)$} & One episode: $110(74.8 \%)$ \\
\hline & & Two episodes: $32(21.8 \%)$ \\
\hline & & Three episodes: $4(2.7 \%)$ \\
\hline & & Four episodes: $(0.7 \%)$ \\
\hline $\begin{array}{c}\text { Acute respiratory tract } \\
\text { infection (ARI) }\end{array}$ & \multicolumn{2}{|c|}{$197(76.4 \%)$} \\
\hline $\begin{array}{c}\text { Lower respiratory tract } \\
\text { infection }\end{array}$ & \multicolumn{2}{|c|}{$32(12.4 \%)$} \\
\hline $\begin{array}{c}\text { Intestinal Worm } \\
\text { (Mother Observation ) } \\
(\mathrm{n}=258)\end{array}$ & \multicolumn{2}{|c|}{$30(11.6 \%)$} \\
\hline
\end{tabular}

Table 5 represents the morbidity pattern and conditions seen among children over a period of three months. Most commonly seen morbidity was ARI 76.4\%, followed by Fever $56.2 \%$. Diarrhoea prevalence was $22.1 \%$; similar finding about prevalence of diarrhoea was seen in the study done in Kashmir, India ${ }^{(31)}$ and WHO report on Ghana, Neonatal and child Health profile ${ }^{(32) \text {. }}$

The children had most frequently experienced one episode of most condition; however, most frequently recurring episodes were due to cough. There were fewer episodes of recurrent diarrhoea $(14 \%)$. 
Table 6: Treatment seeking behaviour and practice of mothers towards children health.

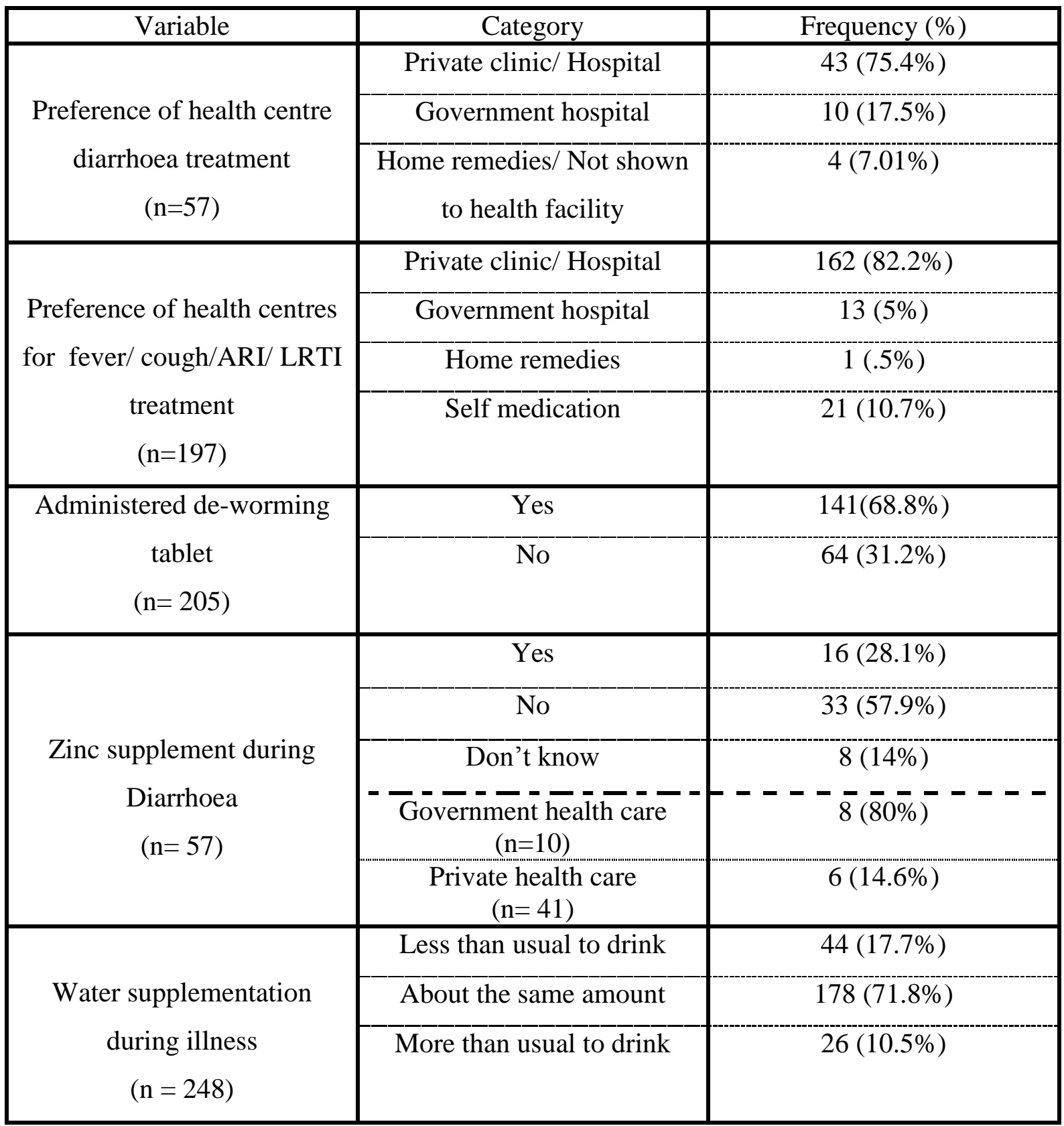

The above table describes about the treatment seeking behaviour and practice of mothers/ primary caregivers during illness of children.

Most participants preferred private clinics for treatment of diarrhoea (75.4\%) and for fever/ cough/ARI/LRTI treatment (82.2\%). In government hospital only $17.5 \%$ and $5 \%$ were shown for diarrhoea and fever/ cough/ARI/ LRTI respectively. 
Table 7: Nutritional status of participant children.

\begin{tabular}{|c|c|c|c|c|c|c|c|c|}
\hline \multicolumn{2}{|l|}{ Variable } & $\begin{array}{l}(3-60) \\
\text { Months } \\
(\mathrm{n}=249)\end{array}$ & $\begin{array}{c}(3-5) \\
\text { Months } \\
(n=13)\end{array}$ & $\begin{array}{l}(6-11) \\
\text { Months } \\
(\mathrm{n}=37)\end{array}$ & $\begin{array}{l}(12-23) \\
\text { Months } \\
(\mathrm{n}=61)\end{array}$ & $\begin{array}{l}(24-35) \\
\text { Months } \\
(\mathrm{n}=48)\end{array}$ & $\begin{array}{l}(36-47) \\
\text { Months } \\
(n=49)\end{array}$ & $\begin{array}{l}(48-60) \\
\text { Months } \\
(n=41)\end{array}$ \\
\hline \multirow{4}{*}{$\begin{array}{c}\text { Weight for } \\
\text { Age } \%\end{array}$} & $\%<-3 \mathrm{SD}$ & 2 & 0 & 2.7 & 0 & 0 & 4.1 & 4.9 \\
\hline & $\%<-2 \mathrm{SD}$ & 16.5 & 15.4 & 10.8 & 13.1 & 20.8 & 22.4 & 14.6 \\
\hline & $\begin{array}{l}\text { Mean Z } \\
\text { Score }\end{array}$ & -0.8 & -0.58 & -0.47 & -0.5 & -0.94 & -1.1 & -1.08 \\
\hline & $\mathrm{SD}$ & 1.2 & 1.29 & 1.02 & 1.24 & 1.1 & 1.22 & 1.22 \\
\hline \multirow{4}{*}{$\begin{array}{c}\text { Length/height } \\
\text {-for-age } \%\end{array}$} & $\%<-3 \mathrm{SD}$ & 7.6 & 15.4 & 2.6 & 8.2 & 6.3 & 12.2 & 4.9 \\
\hline & $\%<-2 \mathrm{SD}$ & 20.8 & 30.8 & 10.5 & 23 & 22.9 & 20.4 & 22 \\
\hline & $\begin{array}{l}\text { Mean Z } \\
\text { Score }\end{array}$ & -0.88 & -1.38 & -0.35 & -0.71 & -1.01 & -1.09 & -1.09 \\
\hline & $\mathrm{SD}$ & 1.45 & 1.46 & 1.43 & 1.6 & 1.26 & 1.48 & 1.3 \\
\hline \multirow{6}{*}{$\begin{array}{l}\text { Weight for } \\
\text { length/height } \%\end{array}$} & $\%<-3 \mathrm{SD}$ & 3.2 & 7.1 & 8.1 & 3.3 & 0 & 2 & 2.4 \\
\hline & $\%<-2 \mathrm{SD}$ & 8.8 & 7.1 & 8.1 & 6.6 & 6.3 & 12.2 & 12.2 \\
\hline & $\%<+2 \mathrm{SD}$ & 4.8 & 14.3 & 5.4 & 4.9 & 4.2 & 4.1 & 2.4 \\
\hline & $\%<+3 \mathrm{SD}$ & 1.6 & 14.3 & 2.7 & 0 & 2.1 & 0 & 0 \\
\hline & $\begin{array}{c}\text { Mean Z } \\
\text { Score }\end{array}$ & -0.41 & 0.61 & -0.23 & -0.21 & -0.58 & -0.69 & -0.68 \\
\hline & SD & 1.36 & 1.74 & 1.48 & 1.35 & 1.18 & 1.23 & 1.32 \\
\hline
\end{tabular}

Table 7 explains about nutritional status of participant children among three to 60 months old children, it shows assessing for weight for age in percentage $2 \%$ of them were below three standard deviation (SD) i.e. severely underweight with $4.9 \%$ of them belonging to 48-60 months of age.

Among Height/ Length for age $7.6 \%$ of children shows sever shortness (< -3SD) and Shortness $(<-2$ SD) shows $20.8 \%$. Sever shortness prevalence has more seen among the age group of three to five months. Among children Weight for length $7.6 \%$ children shows sever thinness $(<-3 \mathrm{SD})$ and thinness $(<-2 \mathrm{SD})$ of $8.8 \%$ and $1.6 \%$ children shows over weight $(<+3$ SD). Prevalence level of low height for age tends to be substantially greater than those of weight- for- height. Similar findings were observed on WHO Global Database magnitude of protein- energy malnutrition (de Onis M et al) ${ }^{(33)}$ 


\section{Figure 3: Weight for age}

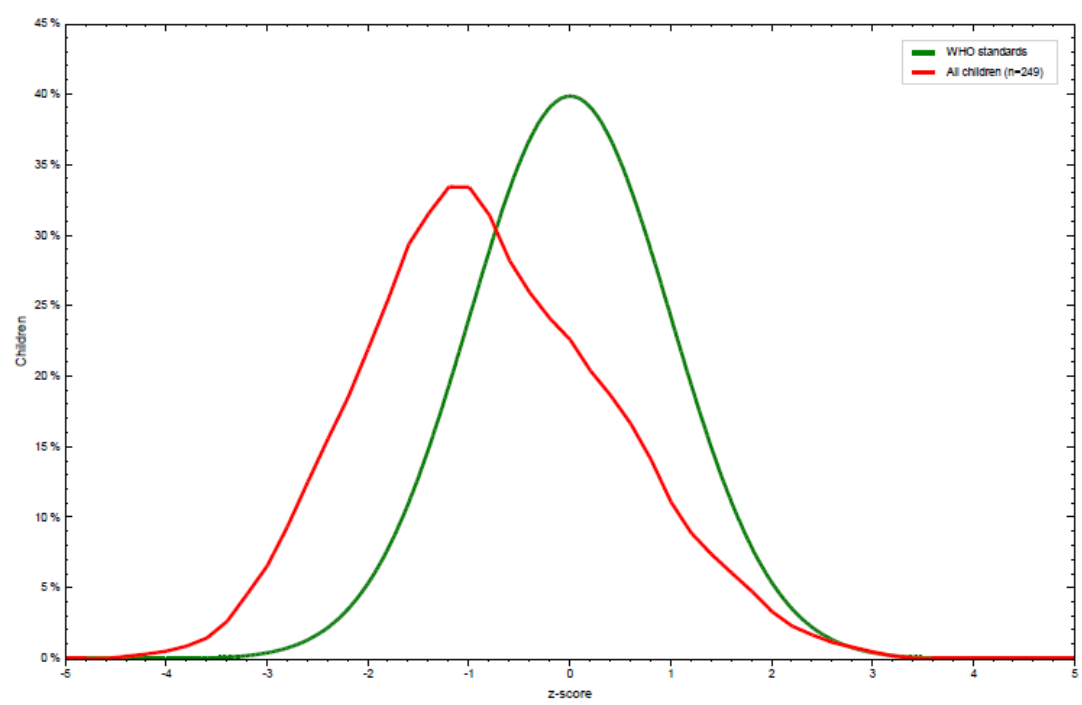

Figure 3: Weight -for -age. By assessing the health status of children on the basis of weightfor-age; $16.5 \%$ children were below the $-2 \mathrm{SD}$ (Z- score) and $2 \%$ children were -3SD.

\section{Figure 4: Length/ Height for age}

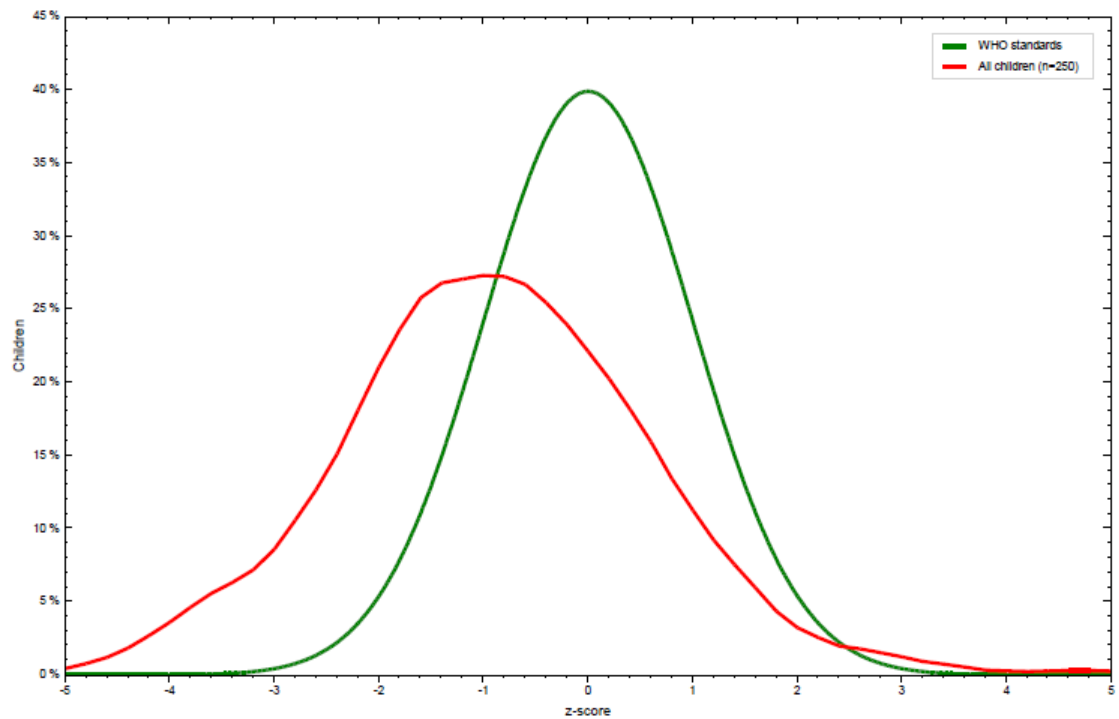

Figure 4: Weight -for-height. Regarding the weight-for-height, $20.8 \%$ children were below the -2 SD (Z- score) and $7.6 \%$ children were below the -3 SD. 
Figure 5: Weight for length

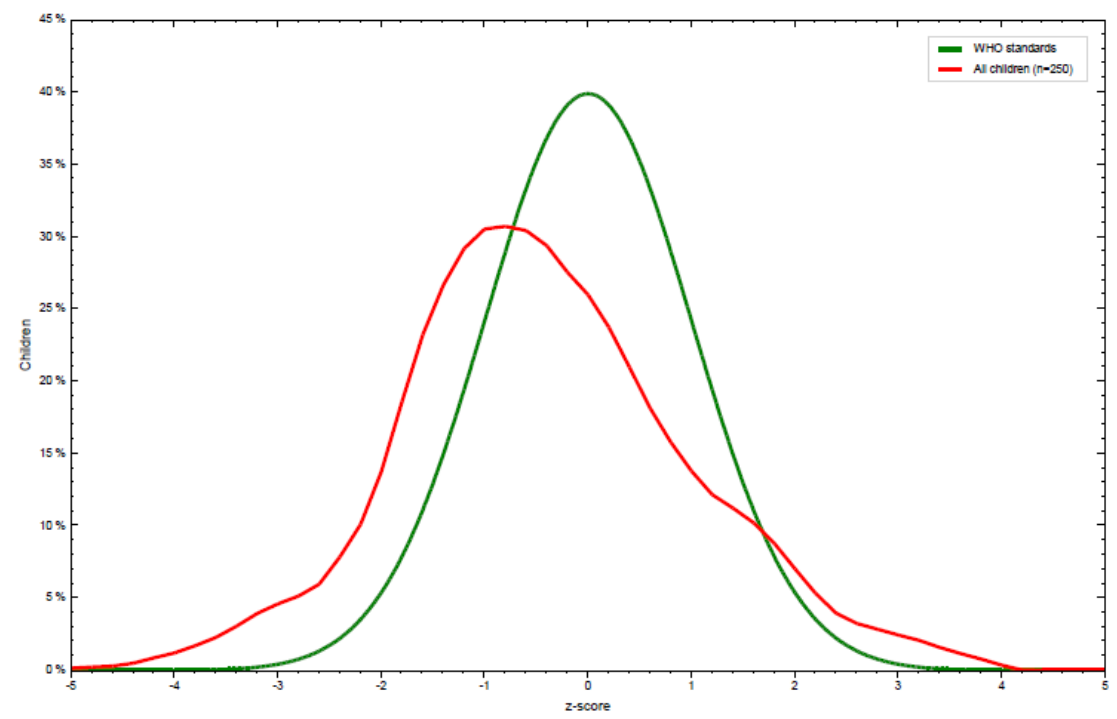

Figure 5: Weight -for-height. Regarding the weight-for-height, $8.8 \%$ children were below the -2 SD (Z- score) and $3.2 \%$ children were below the -3 SD.

Table 8: Difference in nutritional status based on gender of the children

\begin{tabular}{|c|c|c|c|}
\hline \multicolumn{2}{|l|}{ Variable } & $\begin{array}{c}\text { Male } \\
(3-60) \\
\text { Months } \\
(n=112)\end{array}$ & $\begin{array}{c}\text { Female } \\
(3-60) \\
\text { Months } \\
(n=137)\end{array}$ \\
\hline \multirow{4}{*}{$\begin{array}{c}\text { Weight for } \\
\text { Age } \%\end{array}$} & $\%<-3 \mathrm{SD}$ & 1.8 & 2.2 \\
\hline & $\%<-2 \mathrm{SD}$ & 15.2 & 17.5 \\
\hline & Mean Z Score & -0.76 & -0.83 \\
\hline & $\mathrm{SD}$ & 1.22 & 1.18 \\
\hline \multirow{4}{*}{$\begin{array}{l}\text { Length/height } \\
\text {-for-age } \%\end{array}$} & $\%<-3 \mathrm{SD}$ & 9.8 & 5.8 \\
\hline & $\%<-2 \mathrm{SD}$ & 19.6 & 21.7 \\
\hline & Mean Z Score & -1.01 & -0.77 \\
\hline & $\mathrm{SD}$ & 1.4 & 1.48 \\
\hline \multirow{6}{*}{$\begin{array}{c}\text { Weight for } \\
\text { length/height } \\
\%\end{array}$} & $\%<-3 \mathrm{SD}$ & 1.8 & 4.3 \\
\hline & $\%<-2 \mathrm{SD}$ & 9.8 & 8 \\
\hline & $\%<+2 \mathrm{SD}$ & 8 & 2.2 \\
\hline & $\%<+3 \mathrm{SD}$ & 1.8 & 1.4 \\
\hline & Mean Z Score & -0.28 & -0.51 \\
\hline & SD & 1.47 & 1.27 \\
\hline
\end{tabular}


Table 8 explains about Gender nutritional status differences. In compare to boys, female children were found to weigh less for age $(<-3 \mathrm{SD}=2.2,<-2 \mathrm{SD}=17.5)$. Male children were found shorter for length for age in comparison to females $(<-2 \mathrm{SD}=19.6)$. On assessing for thinness females were sever thinness, $9.8 \%$ male, were this in comparison with $8 \%$ of female.

Table 9: Knowledge about causes of diarrhoea and ORS solution.

\begin{tabular}{|c|c|c|}
\hline Variable & Category & Frequency $(\%)$ \\
\hline \multirow{6}{*}{$\begin{array}{l}\text { Knowledge of reasons for } \\
\text { diarrhoea } \\
(n=258)\end{array}$} & Unclean water & $70(27.1 \%)$ \\
\hline & Unclean food & $172(66.7 \%)$ \\
\hline & Weather Change & $43(16.7 \%)$ \\
\hline & Unclean Hands & $35(13.6 \%)$ \\
\hline & Changing feeding Habits & $63(24.4 \%)$ \\
\hline & Beliefs & $13(5.0 \%)$ \\
\hline \multirow{2}{*}{$\begin{array}{l}\text { Oral rehydration solution } \\
\text { Knowledge } \\
(\mathrm{n}=258)\end{array}$} & Yes & $191(74 \%)$ \\
\hline & No & $67(26 \%)$ \\
\hline \multirow{2}{*}{$\begin{array}{c}\text { Knowledge of ORS } \\
\text { preparation } \\
(\mathrm{n}=191)\end{array}$} & Yes & $136(71.2 \%)$ \\
\hline & No & $55(28.8 \%)$ \\
\hline \multirow{2}{*}{$\begin{array}{l}\text { Correct knowledge of sachet } \\
\text { ORS preparation } \\
(\mathrm{n}=136)\end{array}$} & Yes & $78(57.4 \%)$ \\
\hline & No & $58(42.6 \%)$ \\
\hline \multirow{2}{*}{$\begin{array}{l}\text { porrect knowledge of ORS } \\
\text { preparation at Home } \\
(n=136)\end{array}$} & $\bar{Y} \overline{e s}$ & $-27 \overline{(19.9 \%)}$ \\
\hline & No & $109(80.1 \%)$ \\
\hline
\end{tabular}

Table 9: Describes about knowledge about ORS and reason of diarrhoea.

Above stated that diarrhoea was due to unclean food was $66.7 \%$, while $27.1 \%$ stated it was due to unclean water and about 5\% gave the following reasons about beliefs like superstitious. Out of 258 participants, $74.1 \%$ participants are aware or heard about the ORS out of which $71.2 \%$ knows about preparation. Out of $71.4 \%$, about $57.4 \%$ knows correct ORS preparation from the sachet and $19.9 \%$ knows home preparation in the absence of sachet. Similar findings were seen from the DLHS-3 survey about women know what to do when a child gets diarrhoea ${ }^{(26)}$ 
Table 10: Knowledge of ORS among mother/ caregiver of children with diarrhoea

\begin{tabular}{|c|c|c|c|c|}
\hline Variable & Category & \multicolumn{2}{|c|}{ Diarrhoea } & Chi-square \\
\cline { 2 - 4 } & & $\begin{array}{c}\text { Yes } \\
(\mathrm{n}=57)\end{array}$ & $\begin{array}{c}\text { No } \\
(\mathrm{n}=201)\end{array}$ & \\
\hline $\begin{array}{c}\text { Knowledgalue } \\
(\mathrm{n}=258)\end{array}$ & Yes & $50(87.7 \%)$ & $141(70.1 \%)$ & \\
\hline $\begin{array}{c}\text { Knowledge of } \\
\text { Preparation } \\
(\mathrm{n}=191)\end{array}$ & No & $7(12.3 \%)$ & $60(29.9 \%)$ & 0.008 \\
\cline { 2 - 4 } & Yes & $36(72 \%)$ & $100(70.9 \%)$ & 0.885 \\
\hline
\end{tabular}

Table 10: Brief about knowledge of ORS among diarrhoea case.

Knowledge about ORS in mother/ primary care givers among child suffered from diarrhoea was $87.7 \%$. This relationship was found to be statistical significance $(\mathrm{p}<0.05)$. Out of whom $72 \%$ knew about ORS preparation though it was not statistically significant. 
Table 11: Sources of water and water treatment practise

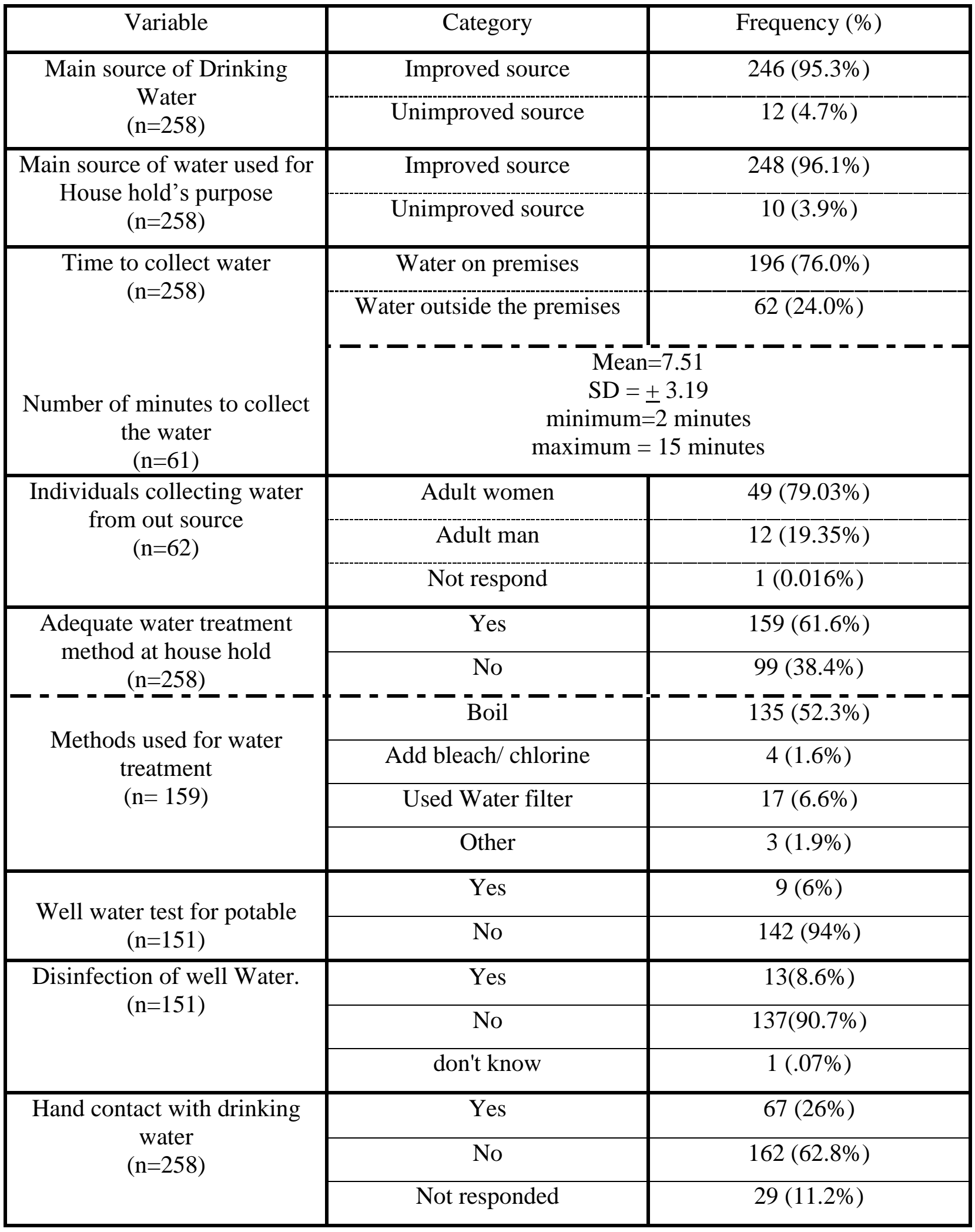


Table 11 Brief about source of water and their handling practice.

The majority i.e. $95.3 \%$ used improved source of drinking water for members of households, out of which $58.1 \%$ drew water from protected dug well followed by piped water into ward $(9.7 \%)$ and dwelling (9.3\%), about $8.9 \%$ participants uses public well and $1.9 \%$ uses tankertruck water. The majority i.e., 96.1 \% used protected water for their house hold purpose. Findings are similar to World Bank report of 2012, improve source of water ${ }^{(34)}$. About $76 \%$ house hold had water on premises and $24 \%$ had to travel outside to collect water for drinking purpose/basic house-hold purpose. The mean total minutes to fetch water from the water collection point to dwelling were $7.15 \pm 3.19$ minutes. Mostly women i.e., $79.03 \%$ of adult women went to fetch the water from the dwelling followed by adult men $12 \%$. More than half i.e., 61.6\% households used adequate water treatment methods; among them $52.3 \%$ used boiling method to disinfect water, followed by water filter $(6.6 \%)$ and bleaching powder (1.6\%).only $6 \%$ house-hold wells has been checked for quality of water for potable purpose and $8.6 \%$ disinfect there well. During handling water, $26 \%$ had hand contact with drinking water. 
Figure 6: distribution of drinking water according to source

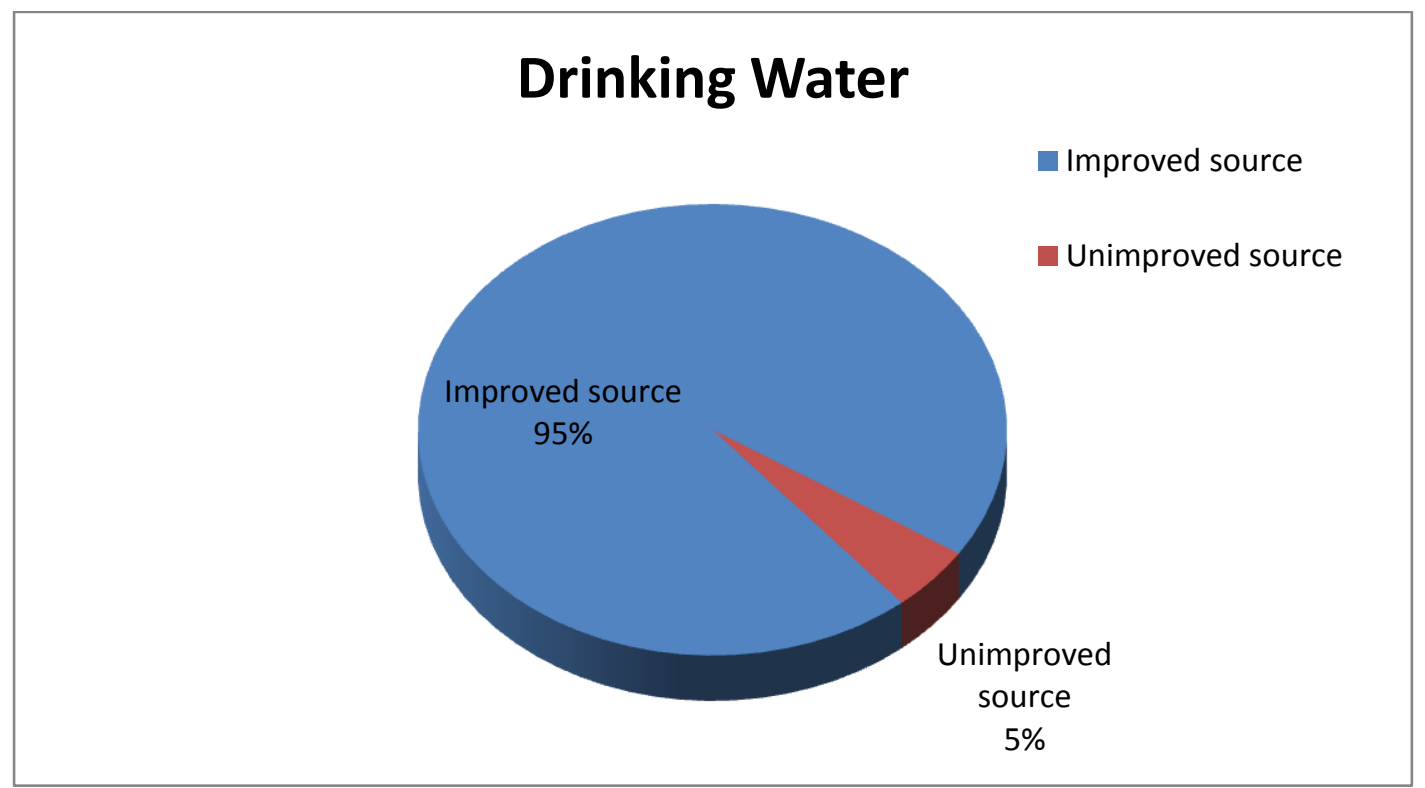

Figure 7: Types of drinking water sources.

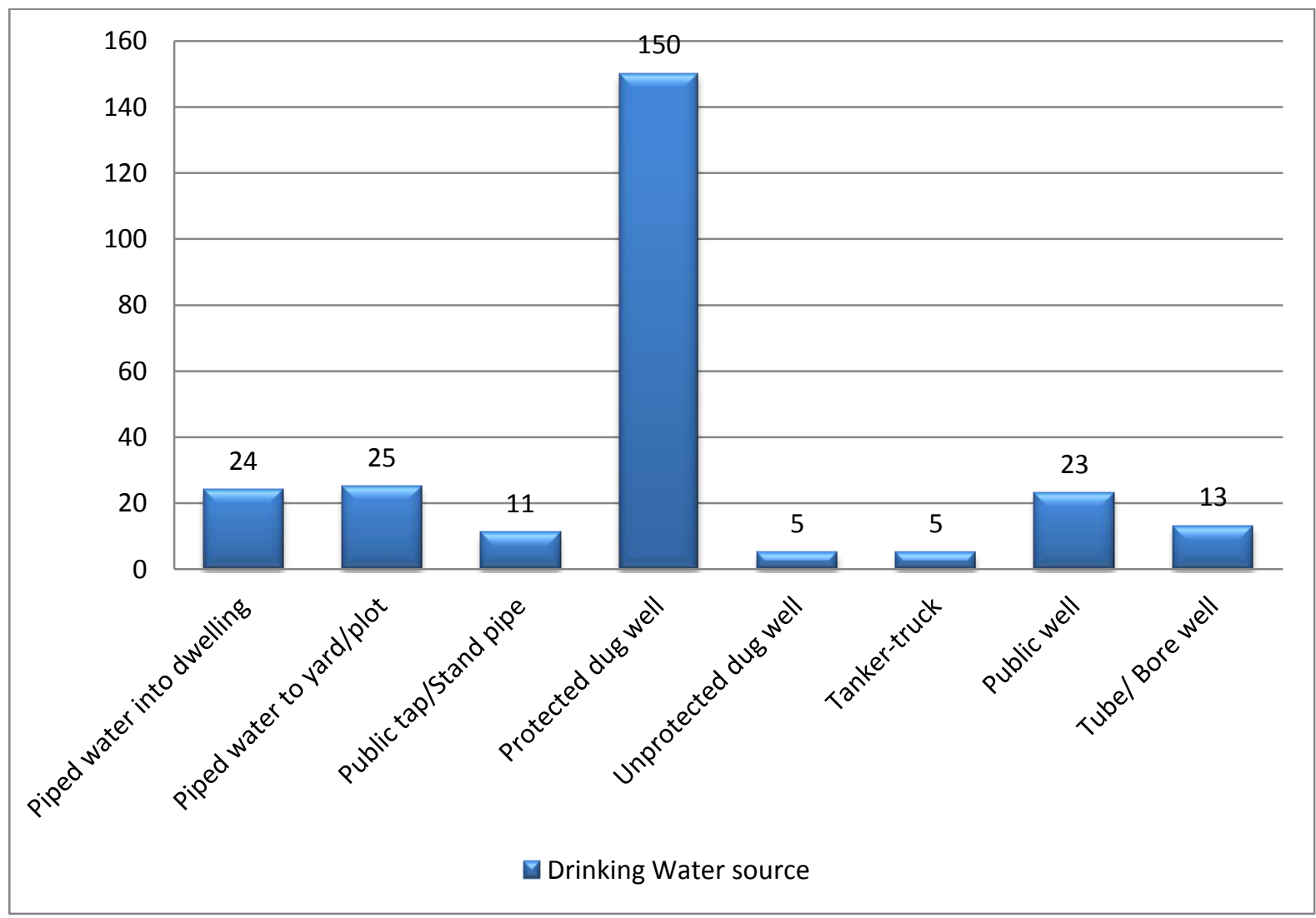


Table 12: Distribution of sanitary facility and practices

\begin{tabular}{|c|c|c|}
\hline Variable & Category & Frequency $(\%)$ \\
\hline \multirow{2}{*}{$\begin{array}{l}\text { Sanitation facility used by } \\
\text { adults in the household } \\
\qquad(\mathrm{n}=258)\end{array}$} & Adequate & $231(89.5 \%)$ \\
\hline & Inadequate & $27(10.4 \%)$ \\
\hline \multirow{2}{*}{$\begin{array}{l}\text { Shared sanitation facility } \\
\qquad(\mathrm{n}=253)\end{array}$} & Yes & $12(4.7 \%)$ \\
\hline & No & $241(95.3 \%)$ \\
\hline \multirow{4}{*}{$\begin{array}{l}\text { Number of households share } \\
\text { that toilets } \\
(\mathrm{n}=12)\end{array}$} & Two house holds & $----\overline{4}(\overline{40} \overline{\%})$ \\
\hline & Three house holds & $3(30 \%)$ \\
\hline & Four house holds & $2(20 \%)$ \\
\hline & Six house holds & $1(10 \%)$ \\
\hline \multirow{3}{*}{$\begin{array}{l}\text { Open Defecation: } \\
\quad(\mathrm{n}=258) \\
-------------\end{array}$} & $----------=$ & --- \\
\hline & Safe disposal & $114(63.6)$ \\
\hline & $\begin{array}{c}\text { Unsafe disposal } \\
-\overline{\text { Child used toilet/ latrine }}-\overline{-}\end{array}$ & $\begin{array}{r}83(36.4) \\
---\overline{57}(31.8 \%)\end{array}$ \\
\hline \multirow{6}{*}{$\begin{array}{l}\text { Disposal of childrens faeces } \\
\text { (less than 3years) } \\
(n=197)\end{array}$} & Put/ rinsed into toilet or latrine & $57(31.8 \%)$ \\
\hline & Put/ rinsed into drain or ditch & $5(2.8 \%)$ \\
\hline & Thrown in to garbage & $5(2.8 \%)$ \\
\hline & Buried & $3(1.7 \%)$ \\
\hline & Left in the open & $11(6.1 \%)$ \\
\hline & Other & $41(22.9 \%)$ \\
\hline \multirow{7}{*}{$\begin{array}{l}\text { Disposal of childrens faeces } \\
\text { (More than 3years) } \\
(\mathrm{n}=79)\end{array}$} & Child used toilet/ latrine & $67(84.3 \%)$ \\
\hline & Put/ rinsed into toilet or latrine & $2(2.5 \%)$ \\
\hline & Put/ rinsed into drain or ditch & $3(3.8 \%)$ \\
\hline & Thrown in to garbage & $2(2.5 \%)$ \\
\hline & Buried & $1(1.3 \%)$ \\
\hline & Left in the open & $3(3.8 \%)$ \\
\hline & Other & $1(1.3 \%)$ \\
\hline
\end{tabular}


Table 12 Describes about the sanitary facility and practices.

Most respondent i.e. $89.5 \%$ used improved sanitary faculty by adult in the house hold. Out of this, $87.2 \%$ used flush/pour to pit latrine followed by $4.7 \%$ of flush/ pour flush to sewage system. Only $1.2 \%$ household practices open defecation. Findings are similar to DLHS -4 . (34). About $4.7 \%$ share their sanitary facility with other households. Among less than 3 years of age, $63.6 \%$ disposed their children's faeces safely, out of which $31.8 \%$ children used toilet and $31.8 \%$ children's stools were dropped into latrine/ toilets.

Table 13: Hygiene practices.

\begin{tabular}{|c|c|c|}
\hline Variable & Category & Frequency $(\%)$ \\
\hline \multirow{3}{*}{$\begin{array}{l}\text { Mother/ care giver hand } \\
\text { washing practice after } \\
\text { defecation } \\
(n=258)\end{array}$} & Yes & $253(98.1 \%)$ \\
\hline & No & $3(1.2 \%)$ \\
\hline & Some times & $2(0.8 \%)$ \\
\hline \multirow{3}{*}{$\begin{array}{l}\text { Washing children/ hand } \\
\text { washing after defecation } \\
(\mathrm{n}=258)\end{array}$} & Yes & $253(98.1 \%)$ \\
\hline & No & $3(1.2 \%)$ \\
\hline & Some times & $2(0.8 \%)$ \\
\hline \multirow{3}{*}{$\begin{array}{l}\text { Hand washing before } \\
\text { preparing food } \\
(\mathrm{n}=258)\end{array}$} & Yes & $210(81.4 \%)$ \\
\hline & No & $40(15.5 \%)$ \\
\hline & Some times & $8(3.1 \%)$ \\
\hline \multirow{2}{*}{$\begin{array}{l}\text { Hand washing before eating } \\
\text { (Mother/ caregiver) } \\
(\mathrm{n}=258)\end{array}$} & Yes & $255(98.8 \%)$ \\
\hline & No & $3(1.2 \%)$ \\
\hline \multirow{2}{*}{$\begin{array}{l}\text { Washing hand before feeding } \\
\text { the children } \\
(\mathrm{n}=258)\end{array}$} & Yes & $255(98.8 \%)$ \\
\hline & No & $3(1.2 \%)$ \\
\hline \multirow{3}{*}{$\begin{array}{l}\text { Child hand washing before } \\
\text { eating } \\
(\mathrm{n}=224)\end{array}$} & Yes & $217(84.1 \%)$ \\
\hline & No & $5(1.9 \%)$ \\
\hline & Some times & $2(0.8 \%)$ \\
\hline \multirow{3}{*}{$\begin{array}{l}\text { Hand washing and feet } \\
\text { washing after returning } \\
\text { school/ going out } \\
(\mathrm{n}=205)\end{array}$} & Yes & $61(29.8 \%)$ \\
\hline & No & $111(54.1 \%)$ \\
\hline & Some times & $33(16.1 \%)$ \\
\hline
\end{tabular}


Table 14: Materials used for washing their hands

\begin{tabular}{|c|c|c|}
\hline Variable & Material used & Frequency $(\%)$ \\
\hline \multirow{3}{*}{$\begin{array}{l}\text { Mother/ care giver Hand } \\
\text { washing practice after } \\
\text { defecation } \\
(\mathrm{n}=258)\end{array}$} & Water only & $83(32.5 \%)$ \\
\hline & With soap and water & $169(66.3 \%)$ \\
\hline & other & $3(1.2 \%)$ \\
\hline \multirow{3}{*}{$\begin{array}{l}\text { Washing children/ Hands } \\
\text { after defecation } \\
(\mathrm{n}=258)\end{array}$} & Water only & $89(34.9 \%)$ \\
\hline & With soap and water & $162(63.5 \%)$ \\
\hline & other & $4(1.6 \%)$ \\
\hline \multirow{3}{*}{$\begin{array}{l}\text { Before preparing food } \\
\qquad(\mathrm{n}=221)\end{array}$} & Water only & $165(74.7 \%)$ \\
\hline & With soap and water & $54(24.4 \%)$ \\
\hline & other & $2(0.9 \%)$ \\
\hline \multirow{3}{*}{$\begin{array}{l}\text { Before eating (Mother/ } \\
\text { caregiver) } \\
(\mathrm{n}=255)\end{array}$} & Water only & $151(59 \%)$ \\
\hline & With soap and water & $99(38.7 \%)$ \\
\hline & other & $5(2.3 \%)$ \\
\hline \multirow{3}{*}{$\begin{array}{l}\text { Washing hand before feeding } \\
\text { the children } \\
(\mathrm{n}=255)\end{array}$} & Water only & $108(42.4 \%)$ \\
\hline & With soap and water & $143(56.1 \%)$ \\
\hline & other & $4(1.6 \%)$ \\
\hline \multirow{3}{*}{$\begin{array}{l}\text { Child washing hand before } \\
\text { eating } \\
(\mathrm{n}=219)\end{array}$} & Water only & $101(46.1 \%)$ \\
\hline & With soap and water & $114(52.1 \%)$ \\
\hline & other & $4(1.8 \%)$ \\
\hline \multirow{3}{*}{$\begin{array}{l}\text { Washing hand and foot after } \\
\text { returning school/ going out } \\
\qquad(\mathrm{n}=97)\end{array}$} & Water only & $47(48.5 \%)$ \\
\hline & With soap and water & $46(47.4 \%)$ \\
\hline & $* *$ other & $4(4.1 \%)$ \\
\hline
\end{tabular}

**Other materials include hand wash, sanitizer, mud, ash

Table 13 and 14 speaks about the hygiene practices of the respondent.

Almost every one i.e., $98.1 \%$ mothers/caregiver wash their hands after defecation, among them $66.3 \%$ used water with soup follow by $32.5 \%$ with water only. $98.1 \%$ mothers/ caregivers wash their kids after defecation, among them $63.5 \%$ used water with soup followed by $34.9 \%$ with water only. Most $(81.1 \%)$ participants wash their hands before preparing the food. Out of this, $74.1 \%$ used only water for the same. Almost all i.e., $98.8 \%$ participants 
wash their hands before feeding the child, $56.1 \%$ used water and soap followed $42.1 \%$ with water. Almost mothers i.e., $84.1 \%$ mother/ caregiver washed their child hands before eating and among them $52.1 \%$ used water and soap.

Table 15: Feeding habits and practices.

\begin{tabular}{|c|c|c|}
\hline \multirow{2}{*}{ Weaning initiated } & \multicolumn{2}{|c|}{$\begin{array}{c}\text { Mean }: 5.41 \text { months } \\
\text { SD= } \pm 1.21 \\
\text { Minimum }=2 \text { month } \\
\text { Maximum }=8 \text { month }\end{array}$} \\
\hline $\begin{array}{c}* * \text { Bottle cleaning method } \\
\text { before feeding the child } \\
(\mathrm{n}=34)\end{array}$ & \multicolumn{2}{|c|}{$\begin{array}{c}\text { With water } \\
\text { With water and soap }\end{array}$} \\
\cline { 2 - 3 } & Boiling the bottle with water & $26(76.5 \%)$ \\
\hline
\end{tabular}

** This question has been asked to children less than 24 months of age

Table 15 shows feeding habits and practices of the children less than 24 months of age.

The mean age of initiating weaning practice $5.41 \pm 1.21$.with minimum and maximum of 2 and 8 months respectively. More than half i.e., $76.5 \%$ use sterilization technique for cleaning the feeding bottle, followed by soap with water 
Table 16: Association of diarrhoea with WASH practices

\begin{tabular}{|c|c|c|c|c|}
\hline \multirow[b]{2}{*}{ Variable } & \multirow[b]{2}{*}{ Category } & \multicolumn{2}{|c|}{ Diarrhoea } & \multirow{2}{*}{$\begin{array}{c}\text { Chi-square } \\
\text { P-value }\end{array}$} \\
\hline & & $\begin{array}{c}\text { Yes } \\
(\mathrm{n}=57)\end{array}$ & $\begin{array}{c}\text { No } \\
(n=201)\end{array}$ & \\
\hline \multirow{2}{*}{$\begin{array}{c}\text { Age } \\
(n=258)\end{array}$} & Less than 2 Years & $39(68.4 \%)$ & $82(40.8 \%)$ & \multirow[b]{2}{*}{0.0001} \\
\hline & More than 2 Years & $18(31.6 \%)$ & $119(59.2 \%)$ & \\
\hline \multirow[t]{2}{*}{ Education of Mother } & Up to Middle school & $19(33.3 \%)$ & $42(20.9 \%)$ & \multirow{2}{*}{0.041} \\
\hline & Above middle school & $38(66.7 \%)$ & $159(79.1 \%)$ & \\
\hline \multirow{2}{*}{$\begin{array}{c}\text { Source of drinking } \\
\text { water } \\
(\mathrm{n}=258)\end{array}$} & Improved & $52(91.2 \%)$ & $194(96.5 \%)$ & \multirow{2}{*}{0.94} \\
\hline & Unimproved & $5(8.8 \%)$ & $7(3.5 \%)$ & \\
\hline \multirow{2}{*}{$\begin{array}{c}\text { Adequate water } \\
\text { treatment method at } \\
\text { house hold } \\
(\mathrm{n}=258)\end{array}$} & Treated (Yes) & $33(57.9 \%)$ & $126(62.7 \%)$ & \multirow{2}{*}{0.51} \\
\hline & Not treated (No) & $24(42.1 \%)$ & $75(37.3 \%)$ & \\
\hline \multirow{2}{*}{$\begin{array}{c}\text { Dispose of children } \\
\text { stool } \\
(\mathrm{n}=258)\end{array}$} & Safe dispose & $48(84.2 \%)$ & $117(88.1 \%)$ & \multirow{2}{*}{0.442} \\
\hline & Unsafe dispose & $9(15.8 \%)$ & $24(11.9 \%)$ & \\
\hline \multirow{3}{*}{$\begin{array}{l}\text { Shared toilet facility } \\
\qquad(\mathrm{n}=253)\end{array}$} & Yes & $6(10.7 \%)$ & $6(3 \%)$ & \multirow{3}{*}{0.017} \\
\hline & No & $50(89.3 \%)$ & $191(97 \%)$ & \\
\hline & $\begin{array}{l}\text { Above middle } \\
\text { school }\end{array}$ & $38(66.7 \%)$ & $159(79.1 \%)$ & \\
\hline
\end{tabular}

Table 16: Explains about the association between diarrhoea and the WASH practices in the community. Significant association was seen by doing Chi-Square test.

Child less than 2 years were more likely to suffer from diarrhoea and chi-square shows an association between age and diarrhoea with statistical significance $(\mathrm{p}<0.05)$. With the prevalence of $68.4 \%$ among less than two years of age. Most cases of diarrhoea were found in homes with improved source of drinking water, adequate treatment of water and those who disposed of children's stool safely. None of these findings were statistically significant and could be due to underlying confounders. While $50 \%$ of those shared toilets facilities had diarrhoea cases this was significantly associated. As the education advances occurrence of the disease is likely to less. Educational status of the mother shows a significant association $(\mathrm{p}<0.05)$ with prevalence of diarrhoea.

Logistic regression shows children's less than 2 years of age has 4.26 (2.10 8.637) odd times more likely to get diarrhoea with $95 \%$ confidential interval, compare to children age group of 
2 to 5 years. This has been adjusted to shared toilet facility, education of mother and ownership of the property.

Table 17: Association between ownership and diarrhoea of the property.

\begin{tabular}{|c|c|c|c|c|}
\hline \multirow[b]{2}{*}{ Variable } & \multirow[b]{2}{*}{ Category } & \multicolumn{2}{|c|}{ Property ownership } & \multirow{2}{*}{$\begin{array}{c}\text { Chi-square } \\
\text { P-value }\end{array}$} \\
\hline & & $\begin{array}{c}\text { Own } \\
(n=216)\end{array}$ & $\begin{array}{l}\text { Rented/Lease/Free } \\
(\mathrm{n}=42)\end{array}$ & \\
\hline \multirow[t]{2}{*}{ Diarrhoea } & Yes & $42(19.4 \%)$ & $15(35.7 \%)$ & \multirow{2}{*}{0.020} \\
\hline & No & $174(80.6 \%)$ & $27(64.3 \%)$ & \\
\hline
\end{tabular}

Table 17 shows regarding the association between ownership of the house and diarrhoea, Children's living in rented/lease/free house are more likely to suffer from diarrhoea, comparing to children living in their own homes. It is statistically significant $(\mathrm{p}<0.05)$. This could be related to the socioeconomic status.

Table 18: Association between WASH and cough

\begin{tabular}{|c|c|c|c|c|}
\hline \multirow{2}{*}{ Variable } & \multirow{2}{*}{ Category } & \multicolumn{2}{|c|}{ Cough } & \multirow{2}{*}{$\begin{array}{c}\text { Chi-square } \\
\text { P-value }\end{array}$} \\
\cline { 2 - 4 } & & $\begin{array}{c}\text { Yes } \\
(\mathrm{n}=147)\end{array}$ & $\begin{array}{c}\text { No } \\
(\mathrm{n}=111)\end{array}$ & \\
\hline \multirow{2}{*}{$\begin{array}{c}\text { Main source of } \\
\text { drinking water }\end{array}$} & Improved & $138(93.9 \%)$ & $108(97.3 \%)$ & \multirow{2}{*}{0.197} \\
\cline { 2 - 4 } & Unimproved & $9(6.1 \%)$ & $3(2.7 \%)$ & \\
\hline \multirow{2}{*}{\begin{tabular}{c} 
Type of Family \\
\cline { 2 - 4 }
\end{tabular}} & Nuclear & $97(66 \%)$ & $70(63.1 \%)$ & \multirow{2}{*}{0.413} \\
\cline { 2 - 4 } $\begin{array}{c}\text { Child Washing } \\
\text { Hand's before } \\
\text { eating }\end{array}$ & Single & $49(33.3 \%)$ & $38(34.2 \%)$ & \\
\cline { 2 - 4 } & Joint & $1(0.7 \%)$ & $3(2.7 \%)$ & \multirow{2}{*}{0.501} \\
\cline { 2 - 4 } & Some times & $2(1.5 \%)$ & $0(0 \%)$ & \\
\hline
\end{tabular}

Table 18 explains about relation between cough and WASH

Majority of i.e., $93.9 \%$ of children suffered from cough lived in households, who are using improved source of drinking water. There was no much difference between occurrence of cough with type of family and child washing hand before eating. 
Table 19: Association of fever with co-morbidities

\begin{tabular}{|c|c|c|c|c|}
\hline \multirow{2}{*}{ Variable } & \multirow{2}{*}{ Category } & \multicolumn{2}{|c|}{ Fever } & \multirow{2}{*}{$\begin{array}{c}\text { Chi-square } \\
\text { p-value }\end{array}$} \\
\cline { 3 - 4 } & & $\begin{array}{c}\text { Yes } \\
(\mathrm{n}=145)\end{array}$ & $\begin{array}{c}\text { No } \\
(\mathrm{n}=113)\end{array}$ & \\
\hline \multirow{2}{*}{ Suffering from cough } & Yes & $105(72.4 \%)$ & $42(37.2 \%)$ & \multirow{2}{*}{$\mathbf{0 . 0 0 0 1}$} \\
\cline { 2 - 4 } & No & $40(27.6 \%)$ & $71(62.8 \%)$ & \\
\hline \multirow{2}{*}{ Running nose } & Yes & $108(74.5 \%)$ & $68(60.2 \%)$ & \multirow{2}{*}{$\mathbf{0 . 0 1 4}$} \\
\cline { 2 - 4 } & No & $37(25.5 \%)$ & $45(39.8 \%)$ & \\
\hline \multirow{2}{*}{ Diarrhoea } & Yes & $33(22.8 \%)$ & $24(21.2 \%)$ & \multirow{2}{*}{0.445} \\
\cline { 2 - 4 } & No & $112(77.2 \%)$ & $89(78.8 \%)$ & \\
\hline
\end{tabular}

Table 19 shows association of co-morbidities diseases with fever.

Almost $72.4 \%$ children who suffered from cough, had fever. Association shows statistical significance $(\mathrm{p}<0.05)$, with chi-square value $(\chi=32.18)$, while $74.5 \%$ children suffered from cough and fever, this association shows statistical significance $(\mathrm{p}<0.05)$, with chi-square value $(\chi=5.995)$. 
Figure 8: Map showing distribution of diarrhoea cases in Udupi taluk

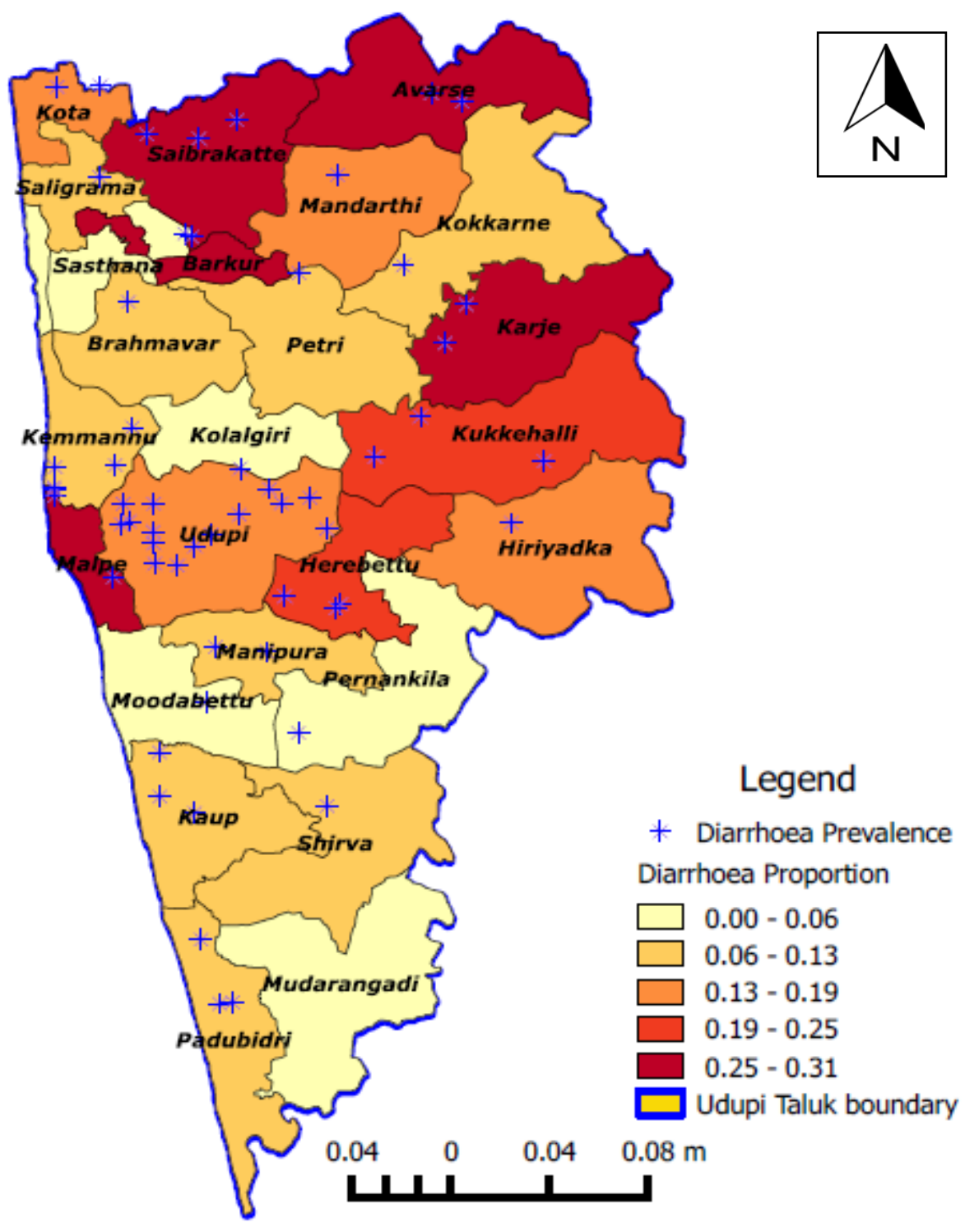

(Source Q GIS version 2.6)

Figure 8 shows distribution of diarrhoea cases according to PHC. Proportion shows distribution of cases in colours yellow $<$ orange $<$ red (0 to 0.31$)$. Prevalence was found to be $22.1 \%$ cases. Malpe, Averse, Siaberkate, Karje has show high proportion of diarrhoea cases. 
Figure 9: Map showing distribution of Case cluster diarrhoea cases

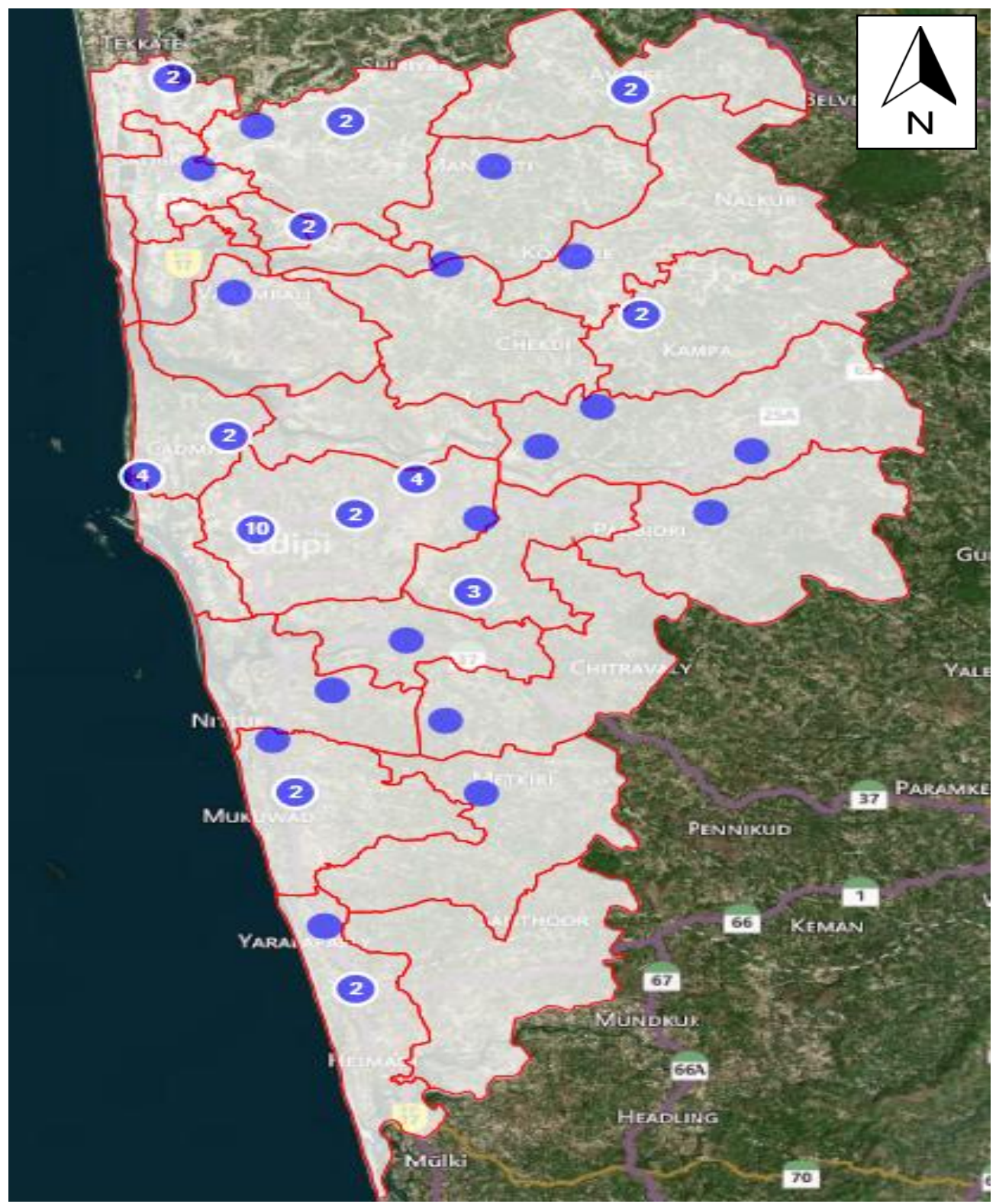

(Source Epi- info 7

The above figure shows case cluster distribution of diarrhoea cases in udupi taluk. Each blue dot represents the cases and the number in the dot shows number of density cases around the area. Towards Malpe area diarrhoea cases were more. 
Figure 10: Map showing distribution of unimproved drinking water source in Udupi taluk

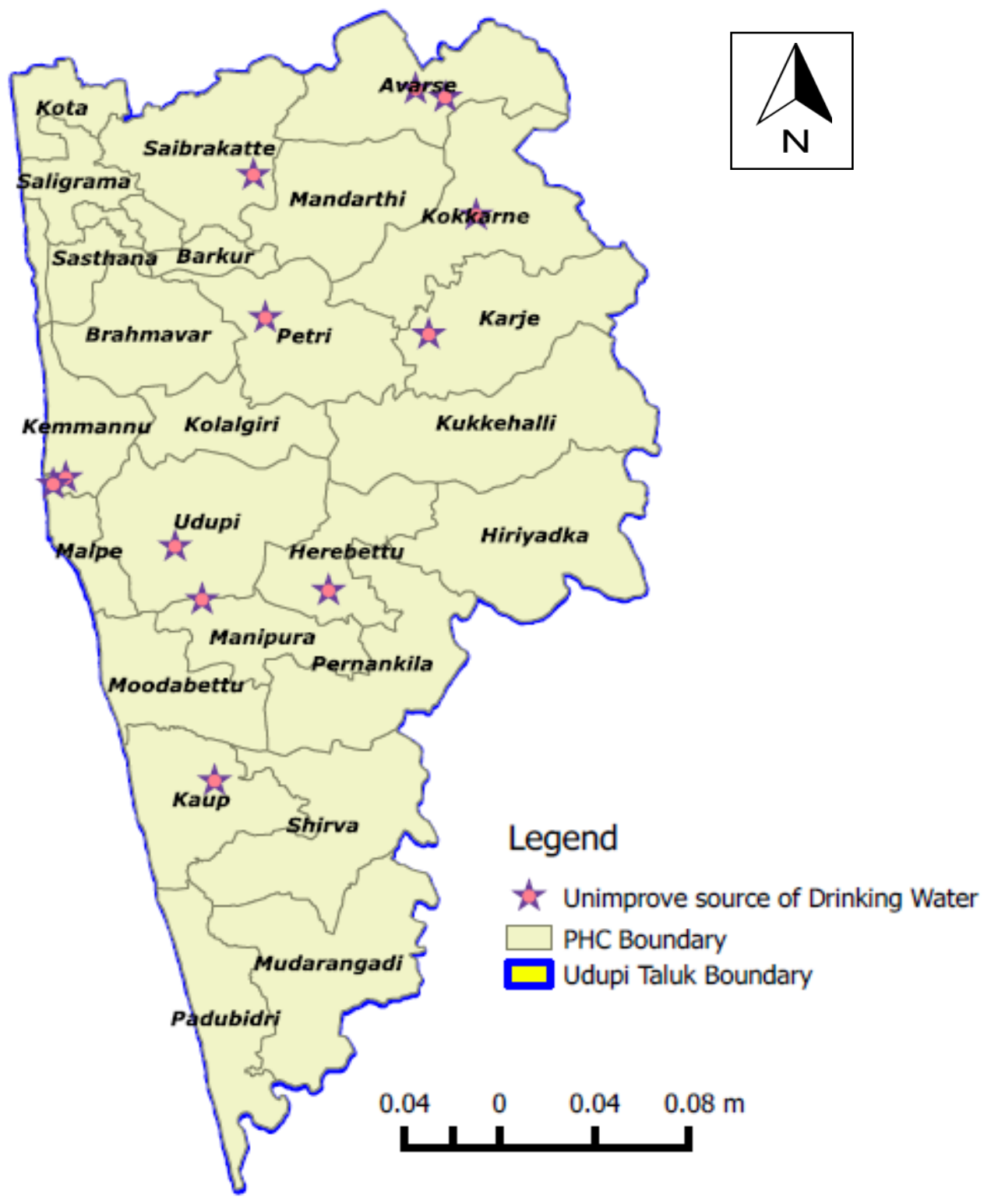

(Source Q GIS version 2.6)

Figure 10 shows distribution of un improved source of drinking water, unimproved water source were found in averse, kokarne, saiberkate, petri, udupi, malpe and kapu areas 
Figure 11: Map showing distribution of fever cases in Udupi taluk

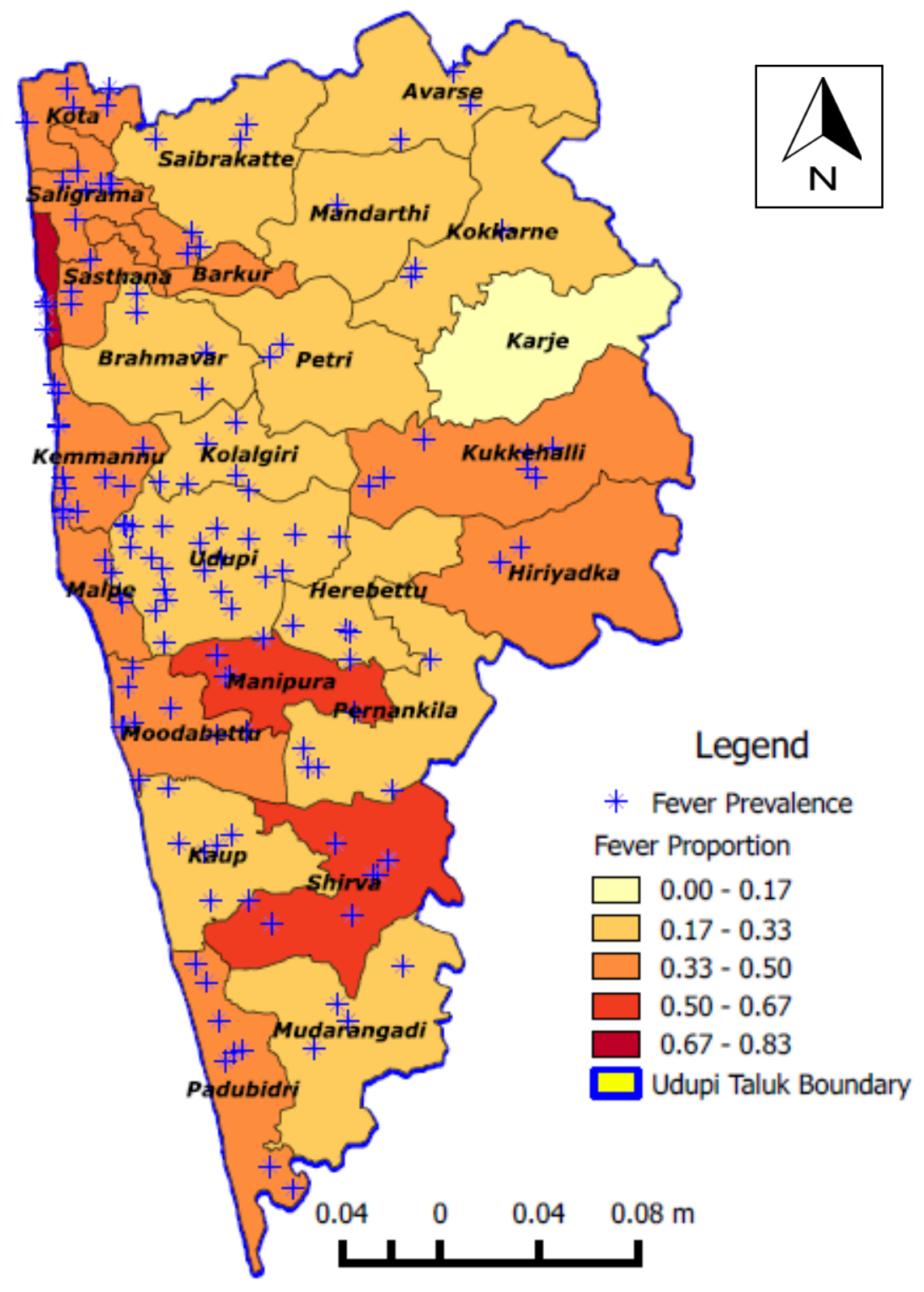

(Source Q GIS version 2.6)

Figure 11 shows distribution of fever cases according to PHC. Proportion shows distribution of cases in colours yellow< orange< red (0 to 0.81$)$. Prevalence was found to be $56.2 \%$. towards west, prevalence of disease was more compare to north east. Kodibengre showed high prevalence. 
Figure 12: Map showing distribution of cough cases in Udupi taluk.

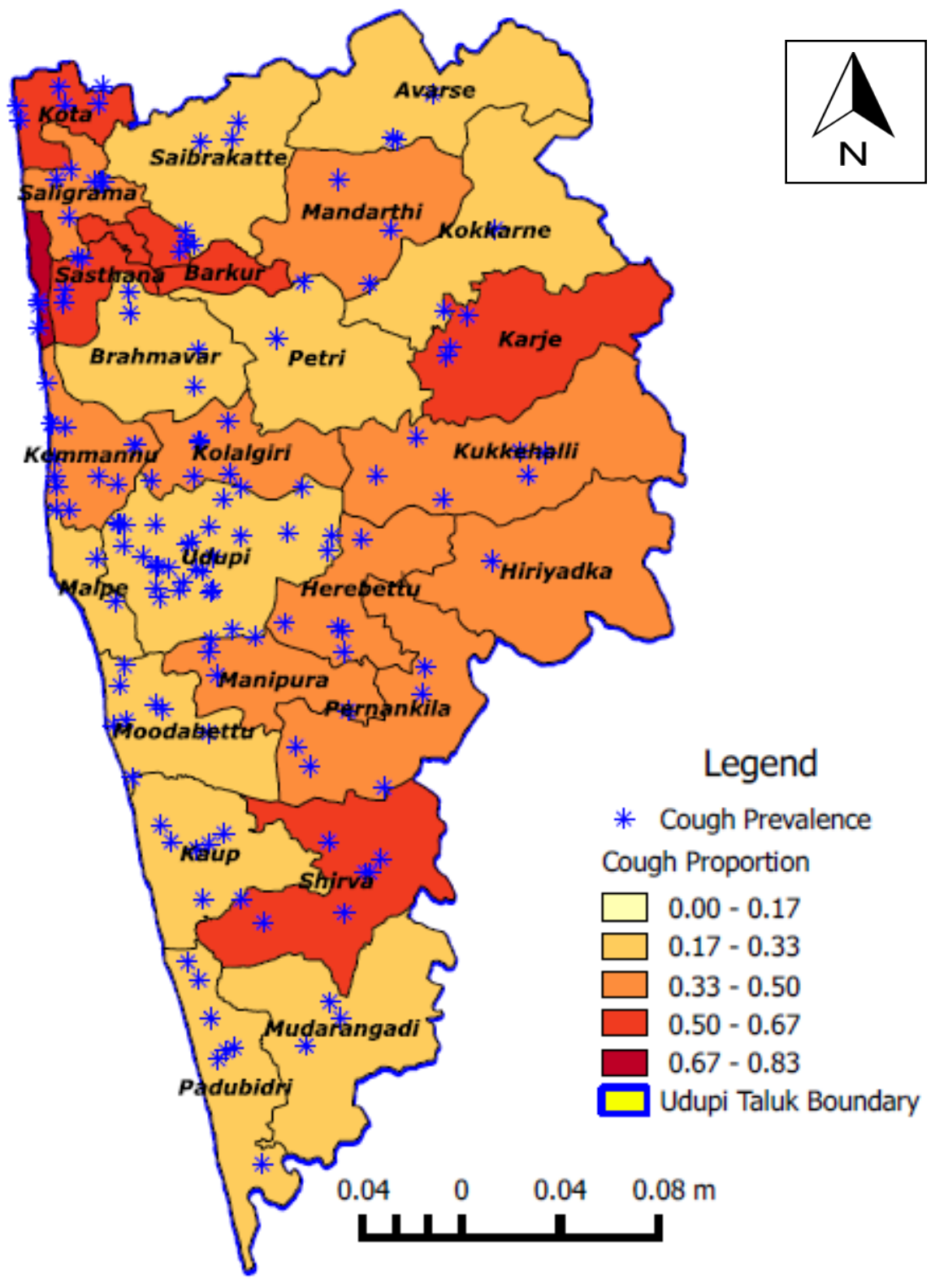

(Source Q GIS version 2.6)

Figure 12 shows distribution of cases with cough according to PHC. Proportion shows distribution of cases in colours yellow $<$ orange $<$ red (0 to 0.83$)$. Towards North West of kota, sasthana, barkur and in Udupi, Shirva prevalence of cough was high. 
Figure 13 : Map showing distribution of lower respiratory tract infection in Udupi taluk

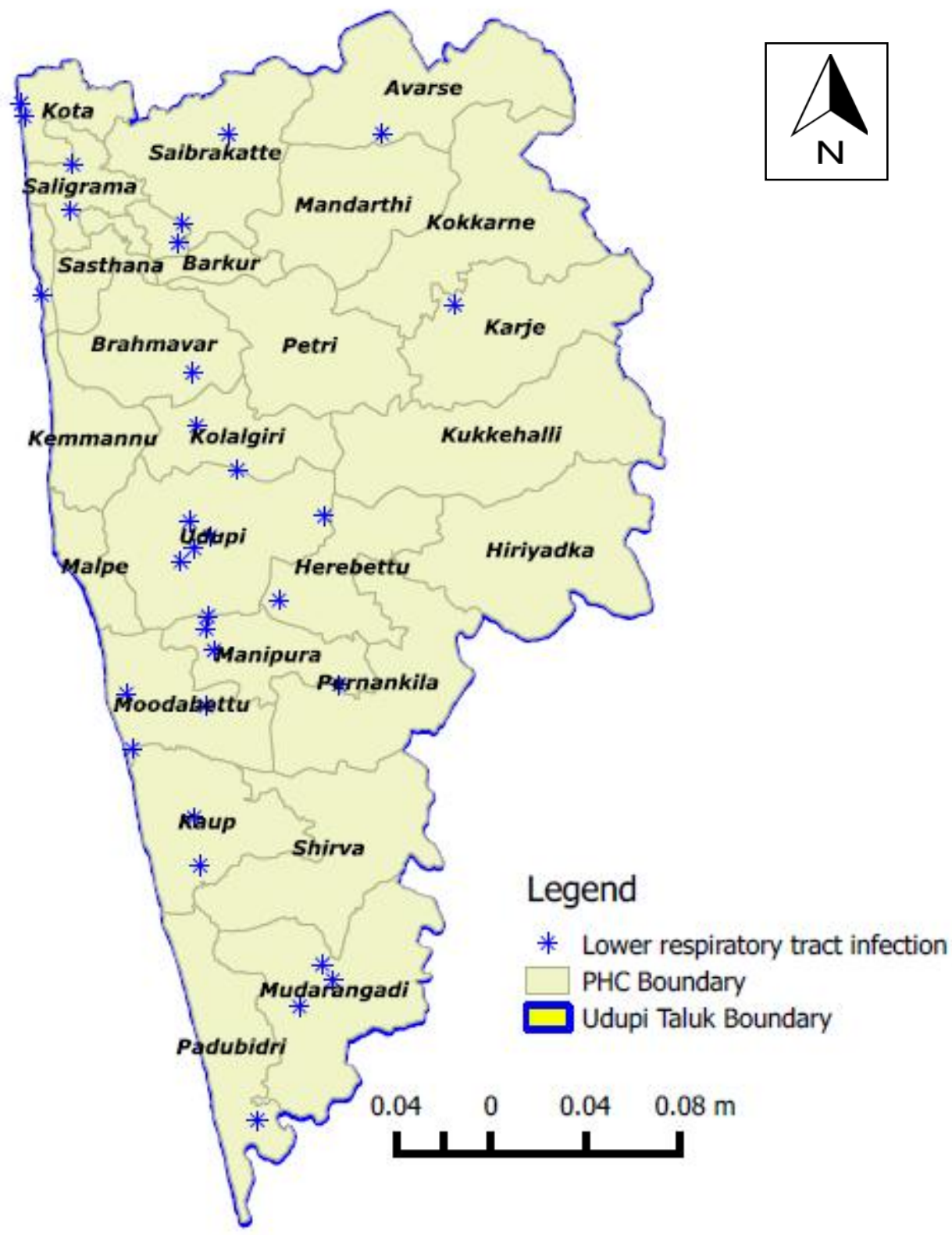

(Source Q GIS version 2.6)

Figure 13 shows distribution of prevalence of LRTI cases. Towards Mudarangadi and towards middle of the udupi taluk around udupi, manipura, barkur, kota and kolalgiri cases were found. 


\section{Remote sensing findings for distribution of diarrhoea cases}

Distribution of sample is more in the regions of coastal area, Udupi town, along the sides of NH-17. Crowd of house were seen in Udupi, Malpe, Saligrama, Kapu and in rest places spacing between the houses were more. Towards Avarse, kokkarne, Karje, Hiriyadka, Perampalli most of the houses are in deep geographic vegetation. Finding shows most of the villages not located too close to river, except in Malpe, kodibengre and sasthana

Figure 14: Distribution of diarrhoea cases with geographical structure of Udupi taluk

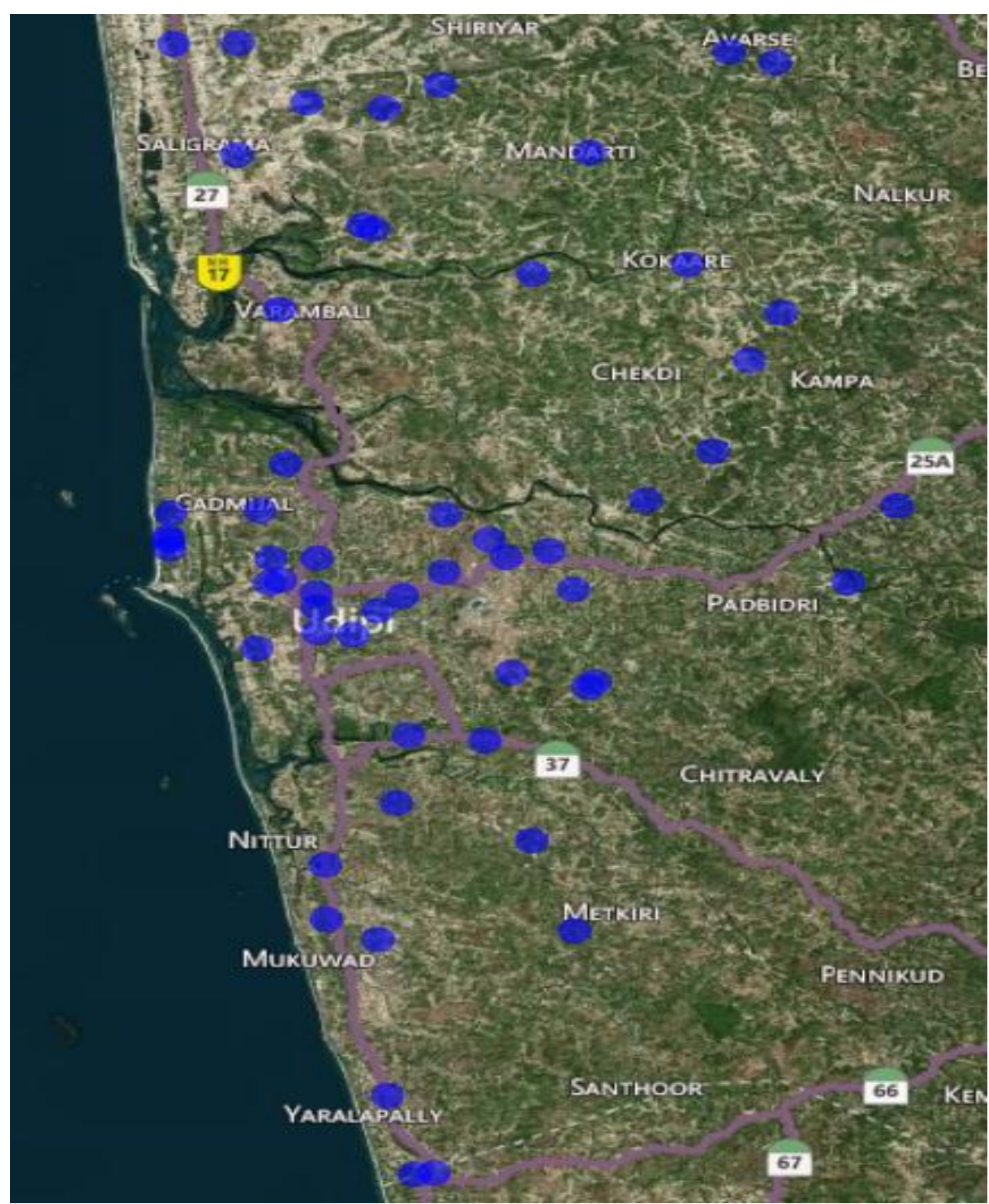

Figure 14 explains about the distribution of diarrhoea cases with relation to geographic structure of Udupi taluk. 
Figure 15: Distribution of diarrhoea case with satellite image in Malpe Beach

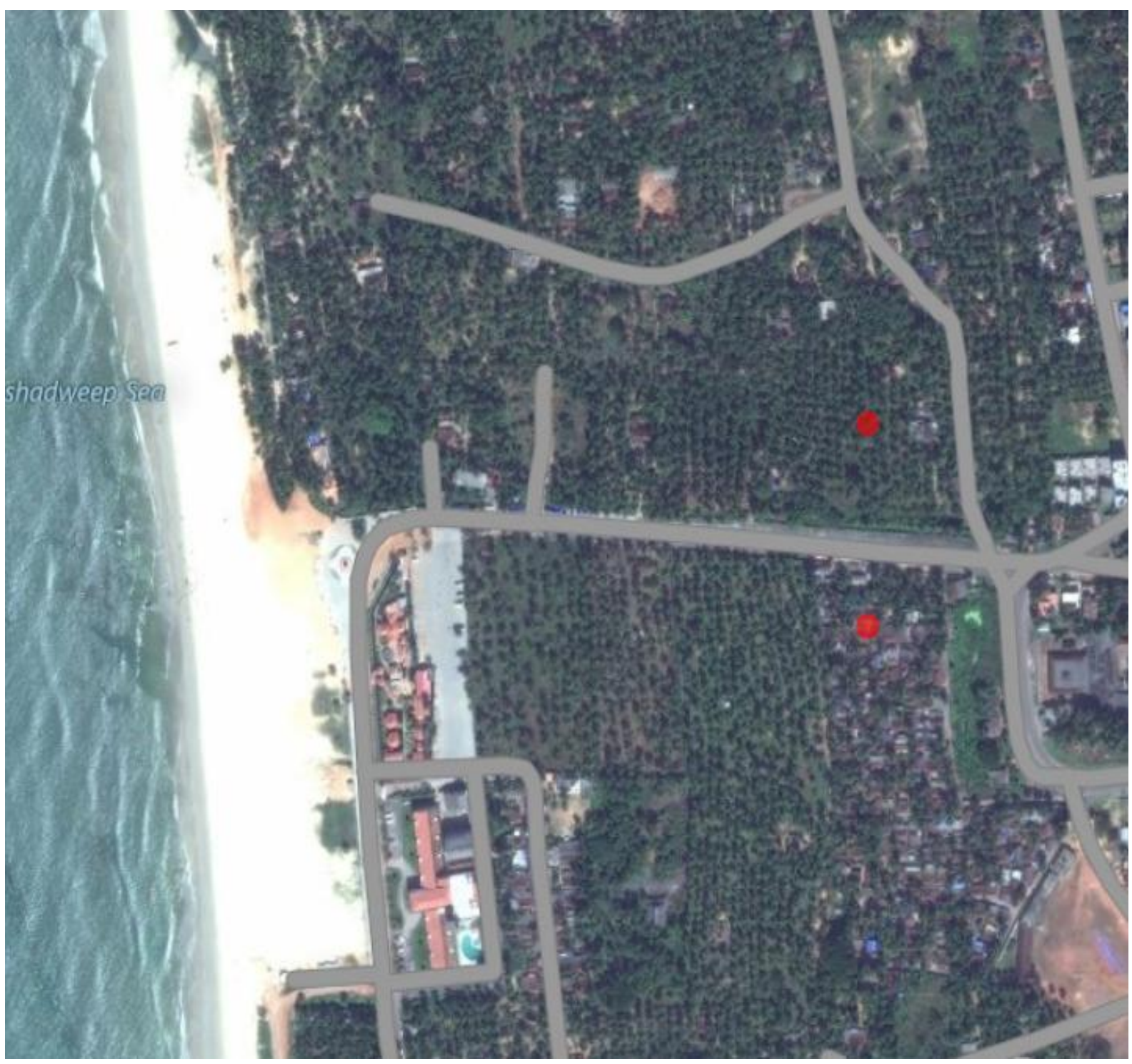

Figure 15: shows distribution diarrhoea cases (red dot) with satellite image. It shows the distribution of vegetation, water body (Arabian sea), distribution of houses with access to road. 


\section{Qualitative component}

The qualitative component was focused on identifying factors related to morbidity pattern and WASH practices among community.

Main stake holders includes: General practitioners, paediatricians, neonatologist, medical officer, auxiliary mid wife, male health worker, social worker, community leaders, Community members.

\section{Geographic Nature}

Udupi taluk share a peculiar geographic distribution with sea, plain and hilly area, socio demography with high to low socio economic status. In rural area home are spread apart compare to urban area and they were built in their own farmland (except government provided lands) and most of them have their own well.

\section{"Everyone has their own well... so they keep there well clean" [Affluent area, medical officer]}

\section{Water}

The common source of drinking water is well water, even in the presence of pipe water at their home premises. In the absence of well water in their premises they collect the water from public well or from other households.

"Panchayathi niru kempuge eruthe adhuke navu baav.......neere kudiyodhu"

"Panchayth water is red in colour so use well water for drinking" [Affluent area, mother participant]

\section{Reason for using unimproved source of drinking water:}

In the northen part of udupi taluk, during summer wells enter into a dry stage. Panchayath's took the responsibility of distribution of water and they supplying once in 3-4 days in tanker.

"Eeevaga bavili nneru kami yathu.. adhuke panchayathi tank neerua balushthivi”"

"Now water level is reduced in well..so we are using panchaythi water"]Affluent area, mother participant]

In the region of Udupi and Malpe unprotected dug wells were used for daily house-hold purpose, these wells were not maintained by owner/ public service provider. Here migrants were the more vulnerable group as they lived close to the river and Udupi drainage system.

Sanitation and Hygiene

The weathers, geography of Udupi helps the community in maintaining sanitation and hygiene in their environment. Drainage system here has not been replaced with modern 
techniques. block in drainage leads to an overflow or expel of the drainage content. As the river bed system of Udupi is good, drainage content mixes with river and with underground water.

“Even some small sanitary pad block the drainage system" [Affluent area, Social worker]

\section{Diarrhoea}

Reasons found for occurrence diarrhoea including: feeding the children with unhygienic food from outside, Unhygienic food, food poisoning from the ceremony/ temple/ festival, rotten chicken and egg, bakery items, fried items, non-veg items like fish and chicken in early period . Prevalence was high in pre monsoon and inearly monsoon season. Among preschool/ anganwadi children un-hygienic hands before eating were said to contribute.

Age: Commonly seen in the age group of 7 th month to 3 years. Was attributed mainly due to the behaviour of the children like mouthing and scrolling over the ground and in mud and introduction of complimentary feeding after 6 months.

"No one looks after the quality of outside food, they are the main culprit" [Affluent area, paediatrician]

In most of the cases doctor's follow symptomatic treatment. In low resource setting, paediatrician not able to identify organism, by clinical findings they predict the organism. In most of the cases they found it's due to viral, rarely they find amoebic or bacillary organisms. Simultaneously in high resource setting (Private) they found mixed organisms (50:50= bacteria: viral). Rota virus is the main cause of viral diarrhoea. By experience they found viral diarrhoea is more common in early and pre monsoon seasons.

Reasons for diarrhoea in high prevalence areas, in the Malpe region may be due to contamination of water from the sewage, high density of population and low socio economic status. In Sairbrekatte, Averse, Karje and Kukkehalli it's due to unimproved source of drinking water, low socio economic status, low education among mothers, tribed communities were living here and most of the population living in remote areas.

"Adhu edhu thindhu bedi yahith....u mostly ice cream erbeku"

"Eat different things that why diarrhoea happen mostly...due to ice cream" [Affluent area, mother participant] 
Reasons of low prevalence of diarrhoea.

The main reason was attributed to geographical structure and living style, most of the houses have their own wells and sanitary facility. Open defecation was not acceptable, if any one practice they consider them uncivilized people.

"Diarrhoea does not often occur occurrence once in a year is also difficult" [Affluent area, medical officer]

Researcher observation: Diarrhoea cases were seen in populations living in un hygienic environment, low socio economic status, applying cow dung around the house among migrant population.

Fever and Cough

Fever and cough are causing mainly due to cross infection from elder people, mothers, siblings, courtyard children's. It's mainly due to urbanization, early entry to pre- school and low immune power.

Among north Indian migrants malaria cases were more common compared to north karnataka [Affluent area, paediatrician]

migrants and sporadic vaccine failure measles were found.

"Padubidri kids joining to bramavara pre-school, infection may travel all the way from padubidri to brahmavar! It's all most more than $20 \mathrm{~km}$ !!!....” [Affluent area, paediatrician]

"We get the cases of measles vaccination failure of sporadic cases" [Affluent area, paediatrician]

Lower respiratory tract infection

Around the region of Mudarangadi and Padubidri acute respiratory infections were common attributed to presence of thermal power plant. 
Summary

67 I P g e 
$\checkmark$ A total of 258 mothers/ primary care givers were interviewed with semi-structured, pretested questionnaire..

$\checkmark$ About $46.6 \%$ of respondents were female and $53.1 \%$ of children sampled belonged to age of more than 2 years.

$\checkmark$ Socio- demographic details showed 39.9\% mother/ primary care giver had high school education, $64.7 \%$ family lived in nuclear families and $83.7 \%$ owned their homes.

$\checkmark$ Pattern of morbidity were assessed for the last three months: Most commonly seen morbidities included cold/ running nose $68.2 \%$, followed by cough $57 \%$, fever $56.2 \%$, diarrhoea $22.1 \%$, lower respiratory tract infection, worm infestation $11.6 \%$ and $16.5 \%$ child shows under weight.

$\checkmark$ Treatment seeking behaviour was commonly at private clinic/ hospital compared to government hospitals.

$\checkmark$ Awareness about ORS was present among of mothers/ caregivers was $74.1 \%$ and participants knowledge on reasons for diarrhoea diseases includes water $27.1 \%$, unclean food $66.7 \%$, changing food habits 24.4 and $13.6 \%$ unclean hands

$\checkmark$ Main source of drinking water in Households from improved source was seen in $95.3 \%$ and $76 \%$ had water on premises. Before drinking, $61.6 \%$ of households used adequate water treatment methods at their household.

$\checkmark$ Most $(89.55 \%)$ adult's used adequate sanitary facilities, $63.6 \%$ disposed their child faeces safely. On assess for hygiene practice, $98.1 \%$ mother/ primary care-givers washed their hands after defecation, among them $66.3 \%$ used water and soap and 98.8\% washed their hands before feeding the child.

$\checkmark$ Chi- square and p- value were used to assess an association between diarrhoea and age of the children, property ownership and education of mother.

$\checkmark$ Fever and cough showed association with statistical significance.

$\checkmark$ Qualitative data reveals main reason for diarrhoea as due to un hygienic, food poisoning, unimproved source of drinking water, Less than 2 years of age was seen to emerge as the high risk group.

$\checkmark$ Distribution of diseases is different according to geographic structure, urbanization and socio economic status. 
Conclusion

69 | P a g e 
Udupi taluk shares different demographic details along the lines of geographic area. With good indicators of health, Udupi shares the highest position in Karnataka state. High economic status population generally live towards the coastal area and towards north east. Towards east of Udupi most of the population living in the interior rural area with lack of facility and their standard of living is low compared to people living towards costal area and along the route of National Highway-66.

This Socio- demographic and geographic distribution showed different morbidity and WASH practices. Highlights distribution of diarrhoea cases were seen towards north east, its due low socio economic status and unimproved water source. Distribution of fever and cough cases were more prevalent towards the coastal area, its due to the suppressed immune power among under five children compare to previous generation, urbanization, cross infection, over crowed of population and early entry of kids to pre- school.

Treatment seeking behaviour at diarrhoea in government hospital is high at $17.5 \%$ for diarrhoea compare to fever/ cough/ LRTI. Prevalence of diarrhoea is high in Averse, Siaberkatte, Karje and Kokarnne where treatment seeking behaviour towards government setting was higher compared to other centres.

The present study found association factors for diarrhoea included, food, un-hygienic practices no association between water and diarrhoea was seen. 


\section{Limitations}


$\checkmark$ Morbidity in different seasons has not been recorded as study duration was limited

$\checkmark$ It was self reported by mother/ primary care giver and there is a possibility of recall bias.

$\checkmark$ Small sample size in some PHC (Kodibengre, Averse, Kokkarne and Karje) 
Recommendations 
$\checkmark$ Supplementation of soap and cross ventilation facility in anganwadi and pre-schools.

$\checkmark$ Decentralization of the current centralized policy on distribution of ORS and zinc supplementation.

$\checkmark$ Training can be provided to private doctors about rehydration and zinc supplementation therapy.

$\checkmark$ Policy to test the private well water for potable

$\checkmark$ Policy to test the out source/ festival/ locally prepared food.

$\checkmark$ Educate the mother to provide hygienic food to children's 


\section{References}


1. Sanitation NG-TptT. UNICEF India. [Online].; n.d/2014 [cited 2014 december 18. Available from: http://www.unicef.org/india/wes_2924.htm.

2. Mahatma Gandhi, K.R. Narayanan and plague. The Hindu. [Online].; 2002 [cited 2014 december 14. Available from: http://www.thehindu.com/thehindu/op/2002/03/12/stories/2002031200180100.htm.

3. organization Wh. Sanitation. [Online].; 2014 [cited 2014 december 11. Available from: http://www.who.int/topics/sanitation/en/.

4. Myles F, Elledge, Mc clatchey. India, Urban sanitayion and the toilet challenge. RTI International. 2013.

5. Bartram J cairncross S. Hygiene, Sanitation, and water: forgotten foundation of health. Plos med. 2010; 7(11)(e 1000367).

6. Annette Prüss,David Kay,Lorna Fewtrell. Estimating the Burden of Disease from Water, Sanitation, and Hygiene at global level. Environmental Health Perspectives. 2002;: p. VOLUME 110.

7. Bank W. Improve water source (\% of population with access). [Online].; n.d/2015 [cited 2015 june 20. Available from: Available from http://data.worldbank.org/indicator/SH.H2O.SAFE.ZS.

8. The United Nations Children's Fund (UNICEF)/World Health Organization (WHO). Diarrhoea :Why children are still dying and what can be done Geneva: UNICEF; 2009.

9. UNICEF India. Nutrition. [Online].; n.d/2014 [cited 2014 December 18. Available from: http://www.unicef.org/india/nutrition.html.

10 UNICEF. Water, sanitation and hygine. [Online].; 2003 [cited 2014 december 11. . Available from: www.unicef.org/wash/index hygiene.html.

11 centre for community economics \& development consultant services. Health and . malnutrition. [Online].; 2014 [cited 2014 december 11. Available from: http://cecoedecon.org.in/healthm.html.

12 Mara D LJSBTD. Sanitation and Health. PLoS Med. 2010; 7(11)(e1000363. doi:10.1371).

13 VHSC Gfuff. National health mission. [Online].; 2013 [cited 2014 december 11. Available from: http://nrhm.gov.in/images/pdf/communitisation/vhsnc/orderguidelines/vhsnc guidelines.p df.

14 budget Ischc4tMm. The hindu. [Online].; 2014 [cited 2014 december 18. Available from: 
. http://www.thehindu.com/news/national/costly-sanitation-campaigns-but-very-little-toshow-for-it/article6479587.ece.

15 Welfare DLHaFs4. International instritute of population science. Ministry of Health and . Family Welfare. [Online].; 2012-13 [cited 2015 june 07. Available from: https://nrhmmis.nic.in/DLHS4/Karnataka/District\%20Factsheets/Udupi.pdf.

$16 \mathrm{~J} \mathrm{~J}$. Does piped water reduce diarrhea for children in rural india? Journal of ecnometrics. . $2003 ;:$ p. $153-173$.

17 unicef wa. Core questions on drinking- water and sanitation for household surveys. who . and unicef; 2006. Report No.: who library cataloguing-in-publication data.

18 duncan M J B, mummery W K. GIS or GPS? A Comparison of Two Methods For . Assessing Route Taken During Active Transport. Am J Prev Med. 2007; 33(1).

19 Bhandari TR. Nutritional Status of Under Five Year Children and FactorsAssociated in . Kapilvastu District, Nepal. Symbiosis. 2013 december.

$20 \mathrm{P}$ aRsT. Association of food-hygiene practices and diarrhea prevalence among Indonesian · young children from low socioeconomic urban areas. BMC Public Health. 2013; 13(977).

21 Tarique, M,d., Huda, N., Unicomb. L., Richard,B., et. Interim evaluation of a large. .

22 goswami N D. heecker E J. Vickery C Ahearn M A et. Geographic Information System. based screening foeTB,HIV, and syphilis(GIS-THIS):a cross sectional study. plos one. 2012; 7(10)(e46029).

23 bartram j. cairncross S. Hygiene, Sanitation, and water: forgotten foundation of health. . Plos med. 2010; 7(11)(e 1000367).

24 Hoque B A, Juncker T et al. Sustainability of a water, sanitation and hygiene education - project in rural Bangladesh:a 5-year follow-up. Bulletin. Geneve: world Health organization, Head, Environmental Health Programme, International Centrefor Diarrhoeal Disease Research, Bangladesh (ICDDR,B),; 1996.

25 patil mail S R. arnold F B. Salvatore A. et. The Effect of India's Total Sanitation . Campaign on Defecation Behaviors and Child Health in Rural Madhya Pradesh: A Cluster Randomized Controlled Trial. plos medicine. 2014; DOI: 10(1371).

26 singh N K, Kokiwar P R. Study on morbidity among under- five childern of a rural area of . manipur, thanga: A cross sectional study. Journal of evolution of medical and dental science. 2013 april; 22:(16)(96-101).

27 Clasen T, Boisson S et al. The effect of improved rural sanitation on diarrhoea and 
. helminth infection: design of a cluster-randomized trial in Orissa, India. Emerging Themes in Epidemiology. 2012; 9(7).

28 Ansari M A, Khan Z, Khalique N. Helath profile of under- five in ruaral areas of Aligarh, . India. India J Med Res. 2009 November;(579-583).

29 M.A. Ansari, Z. khan, I.M. Khan. A clinico social study to assess the magnitude of - diarrhoeal diseases among children in rural areas of Alligarhi. Sri ramachandra journal of medicine. .

30 district U. Census 2011 data. [Online].; n.d/2015 [cited 2015 june 02. Available from: · www.census2011.co.in/census/district/268-udupi.html.

31 Siraj Fayaz Ahmed, farheen A. Prevalence of Diarrhoeal Disease, its Seasonal and Age . Variation in under- fives in Kashmir, India. Int J Health Sci (Qassim). 2008 July; 2(2).

32 WHO. Department of Maternal ncaa. [Online].; 2012 [cited 2015 june 17. Available from: . http://www.who.int/maternal_child_adolescent/epidemiology/profiles/neonatal_child/gha. pdf.

33 al dOMe. The Worldwide magnitude of protein-energy malnutrition : an overview from - the WHO Global Database on Child Growth. Bulletin of the World Health Organization. 1992; 122(1105-1110).

34 science. Iiop. Ministry of Health and Family Welfare,District Level Household and . Facility survey -4. [Online].; 2012-13 [cited 15 june 2015. Available from: https://nrhmmis.nic.in/DLHS4/Karnataka/District\%20Factsheets/Udupi.pdf. 


\section{Annexures}




\section{Annexures 1: Subject information sheet}

Introduction of self:

Hi my name is Dr. Yogish C B , am studying 2nd year Master of Public Health in Manipal University, Manipal.

Please read this form carefully, if you do not understand the language or any information in this document, Please discusses with the principal investigator (Yogish). If you decided to volunteer to take part in this study you must sign at the end.

Introduction about the study

Mahatma Gandhi quoted in 1923 that "Sanitation is important than political Independence". Millennium development goals seven and four speak about ensuing environmental sustainability and reduce child mortality. Globally one in five defecates in open, India accounts $60 \%$ of it. Adequate sanitation, hygiene and water are the basic fundamental to health. By fallow above this we can prevent $6.8 \%$ of DALY lost. Indisposed Hygiene and sanitation services are likely to occurrence of Diarrhoea, Intestinal helminthiasis, Cholera, typhoid, respiratory infection, vector born diseases, giardiasis, trachoma, skin and eye infection. GIS provides epidemiological, sociological, clinical and economic data with reference to space.

Back ground of the study

Worldwide unsafe water, inadequate sanitation or insufficient hygiene lead to $80 \%$ of the diarrhoea. $50 \%$ of the underweight or malnutrition is associated with repeated diarrhoea or intestinal nematode infections as a result of unsafe water, underweight contributing $35 \%$ of all deaths. Under the age of five, diarrhoea alone takes away the life of 1.4 million children preventable death per year, Underweight children are more vulnerable to all infectious diseases, 1.2 million people die every year out of which $90 \%$ of whom children are under 5 years. In India Over 50\% of the population defecating in the open, Only $6 \%$ of rural children under the age of five use toilet, $80 \%$ of the children stool thrown to the garbage or left in the open, $44 \%$ mother disposing their children's faces in open, only $11 \%$ of families dispose the children stool safely. There is a high risk of microbial contamination with water and food. . Under the five years diarrhoea is the second biggest cause of death cause by poor Water sanitation and hygiene. Over $40 \%$ of the diarrhoea and $30 \%$ of the respiratory infection among children can be reduced particularly by practicing hand wash with soap after contacted with excreta. Morbidity among under five remains challenging. Mothers and care givers are directly linked with the children's health. Importance of sanitation, Hygiene and pure drinking water receives less attention in the community.

Who can take part?

Under- five children, mothers/ caretakers and stake holders like community leaders, grass root health workers. 
Information about the study

- A total of 280 Mothers/ care givers and children are expected to participate

- A set of semi structured questionnaire on WASH practices and Morbidity pattern of the child will be asked, it will take around 30 to $40 \mathrm{~min}$ to complete.

- None of the questions are sensitive or embarrassing

- Anthropometric measurement of under five children will be measured like Height and weight, and general examination will be done.

Your role and responsibility

You are invited for participation to provide information on WASH practices and Morbidity of U5 children.

What are the risks?

There is no potential risk in the study except for participants losing their information. The information provided by the participants will be treated as confidential. This proposal has been reviewed and approved by the Institutional review committee, Manipal University which is a committee whose task it is to make sure that participants are protected from harm.

What are the potential benefits of participating in the study.

This study may prove beneficial for the students and community by generating evidence on WASH practices and under five (U5) morbidity Pattern using geographic information system in Udupi Taluk.

Confidentiality of information.

The information provided will be treated as confidential, and no one else except me and my guide will have access to the information documented during your interview.

Voluntary participation.

- Whether or not you take part is your choice. If you do not wish to participate, you do not have to give a reason.

- You have the right to access information collected as part of the study

Contact details in case of any questions

Name: Dr.Arthi roa

Address: Department of public health, Manipal University

Email: arthimph@gmail.com

Phone: 9008418848 


\section{Annexure 2: Informed consent form}

Project title: A study on WASH practices and under five (U5) morbidity pattern using remote sensing and geographical information system in Udupi Taluk.

Name of the Research Subject:

Age of the Research Subject:

I have read the Participant Information Sheet and its contents were explained. I had the opportunity to ask questions and received satisfactory answers.

I understand that my participation in the study is voluntary and that I have the right to withdraw at any time without giving any reason, without my medical care or legal rights being affected.

I agree to take part in the above study. I confirm that I have received a copy of the Participant Information Sheet along with this signed and dated informed consent form. 


\section{INFORMED CONSENT FORM(Pediatric group)}

Project title: A study on WASH practices and under five (U5) morbidity pattern using remote sensing and geographical information system in Udupi Taluk.

Name of the Research Subject:

Age of the Research Subject:

I have read the Participant Information Sheet and its contents were explained. I had the opportunity to ask questions and received satisfactory answers.

I understand that my child's participation in the study is voluntary and that my child has the right to withdraw at any time without giving any reason, without my child's medical care or legal rights being affected.

I agree to my child taking part in the above study. I confirm that I have received a copy of the Participant Information Sheet along with this signed and dated informed consent form. 


\section{Annexure -3: Questionnaire}

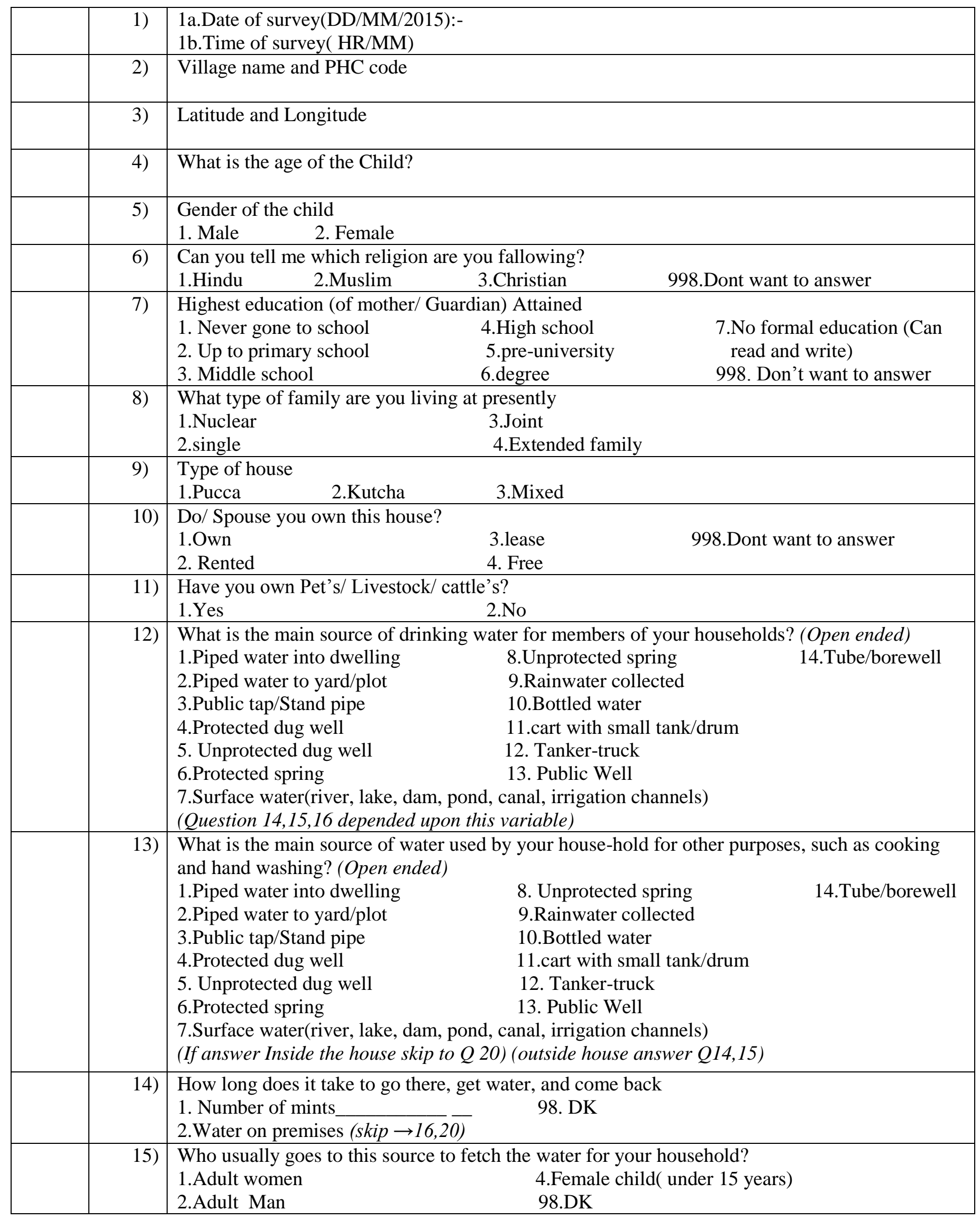




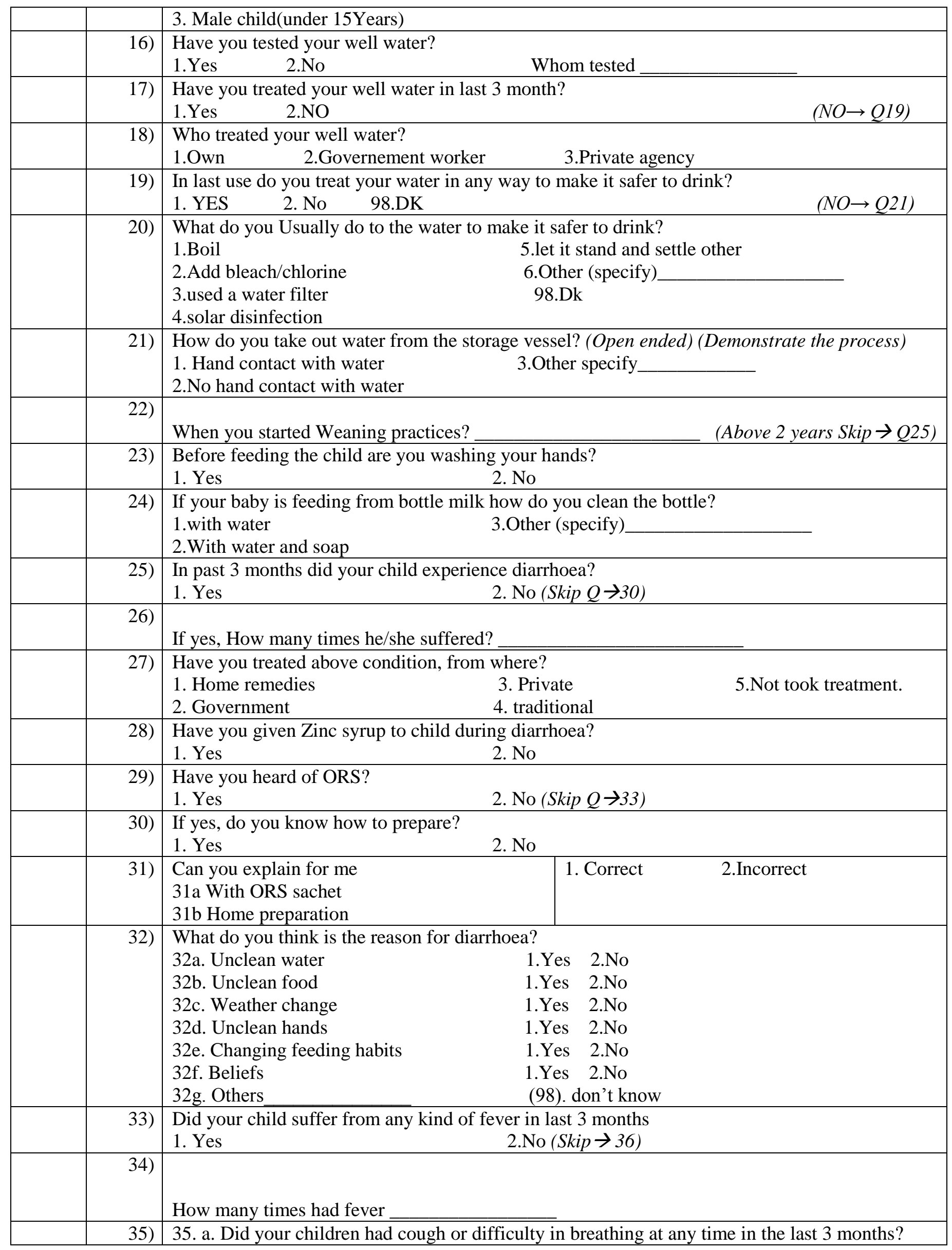




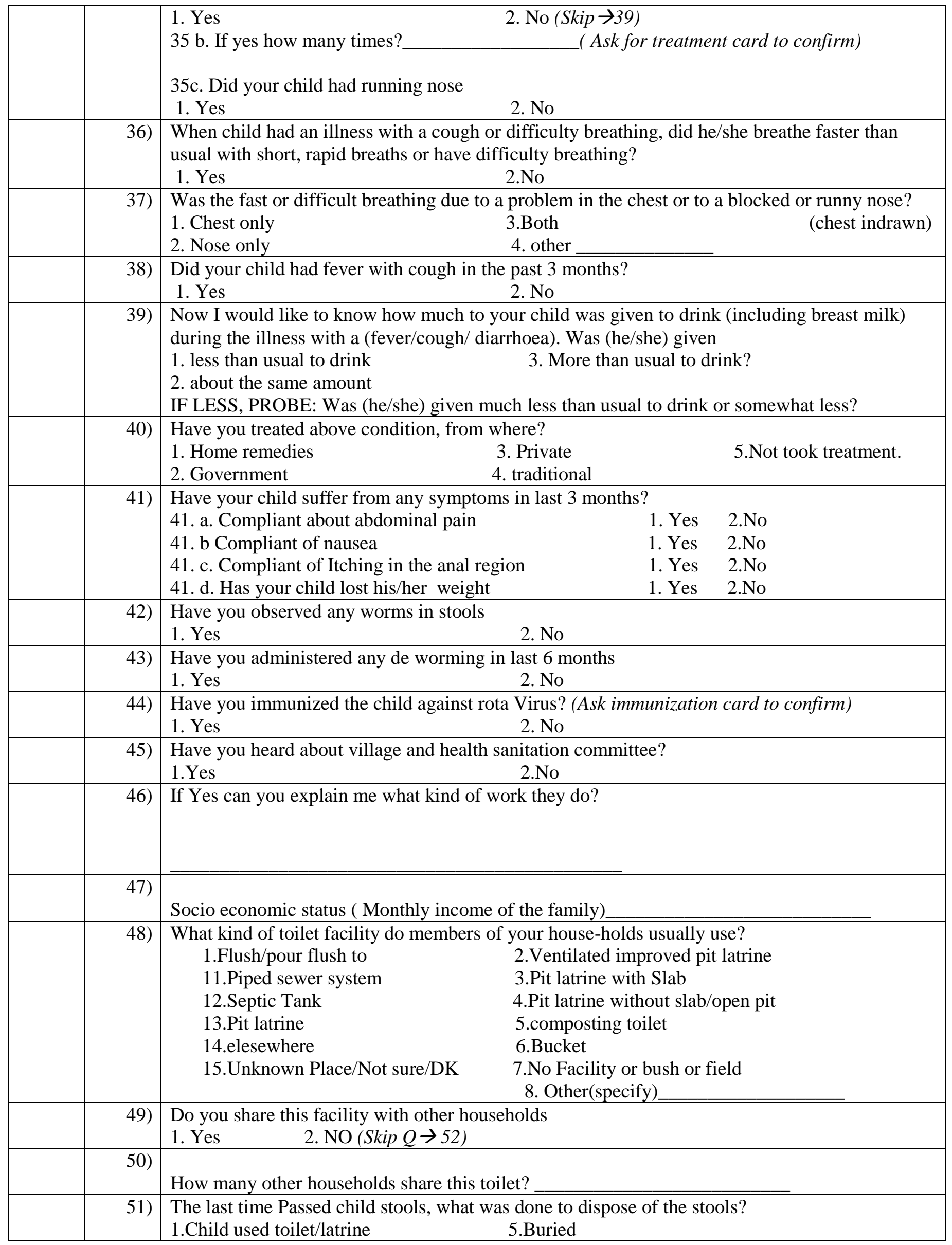




\begin{tabular}{|l|l|ll|}
\hline & & 2.Put/rinsed into toilet or latrine & 6.Left in the open \\
& & 3.Put/rinsed into drain or ditch & 7.Other(specify) \\
\hline & $52)$ & 4.Thrown into garbage & 8.DK \\
\hline & & How frequently your chid pass the stools \\
\hline
\end{tabular}

53) Do you wash hands in fallowing situations and what material do you use? (Last time)

\begin{tabular}{|l|l|l|l|l|}
\hline Situation & Yes & No & Sometimes & $\begin{array}{l}\text { If yes, what material do you use, } \\
\text { with 1) water only 2) with soap and } \\
\text { water 3) with ash/ soil and water, } \\
\text { 4)others (specify) }\end{array}$ \\
\hline 53.a.After defecation & & & & \\
\hline 53.b.Before preparing food & & & & \\
\hline 53.c.Before eating & & & & \\
\hline 53.d.Before feeding the children & & & & \\
\hline
\end{tabular}

54) Does your child wash hands in the following situations and what material do they use?

\begin{tabular}{|l|l|l|l|l|}
\hline $\begin{array}{l}\text { Situation } \\
\text { (Last time) }\end{array}$ & Yes & No & Some times & $\begin{array}{l}\text { If yes, what material do you use, with 1) water } \\
\text { only 2) with soap and water 3) with ash/ soil and } \\
\text { water, 4)others (specify) }\end{array}$ \\
\hline 54.a.After defecation & & & & \\
\hline 54.b.Before eating & & & & \\
\hline $\begin{array}{l}\text { 54.c.When they return } \\
\text { from school/going out }\end{array}$ & & & & \\
\hline
\end{tabular}

55) Physical examination of child

55a.Height/ Length:-

55b.Weight:-

55c.Mid arm circumference:-

55d.Physical examination for clinical features (current status):

Qualitative data: Why? How? 


\section{Annexure -4: Institutional Ethical Clearance Certificate}

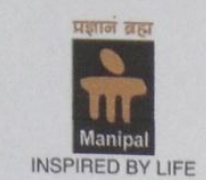

\section{Kasturba Medical College, Manipal}

Institutional Ethics Committee

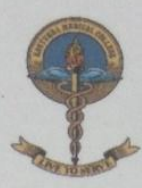

Communication of the Decision of the Institutional Ethics Committee

KMC IEC 41/2015

Saturday,17th January 2015

\begin{tabular}{|c|c|c|}
\hline Protocol title & : & $\begin{array}{l}\text { A study on WASH practices and under five (U5) morbidity } \\
\text { pattern using remote sensing and geographical information } \\
\text { system in Udupi taluk. }\end{array}$ \\
\hline Principal Investigator & : & Dr. Yogish C B \\
\hline Guide / Co Guide / Co Investigators & $:$ & $\begin{array}{l}\text { Dr. Varalakshmi Chandra Sekaran, Dr. Sanjay M } \\
\text { Pattanshetty, Dr. Shreemathi S Mayya }\end{array}$ \\
\hline Name \& Address of Institution & : & Dept. of Public Health, Dept. of Statistics, MU, Manipal. \\
\hline New review & : & New \\
\hline Date of review (DD/MM/YYYY) & : & 16.01.2015 \\
\hline $\begin{array}{l}\text { Decision of the IEC } \\
\text { - Approved } \\
\text { - Pending } \\
\text { - Revision } \\
\text { - Rejected }\end{array}$ & : & Approved from 16.01 .2015 \\
\hline Remarks & : & $\begin{array}{l}\text { Approved for the study period of } 6 \text { months as mentioned in } \\
\text { protocol. The final report has to be submitted at the end of the } \\
\text { study }\end{array}$ \\
\hline
\end{tabular}

Please Note*

* Inform IEC in case of any amendments to the protocol, change of study procedure, site and Investigator and premature termination of study with reasons along with summary.

* Study completion Report to be submitted to IEC.

* Members of IEC have right to monitor the Study with prior intimation.

* A copy of the consent document to be given to the study participant giving the consent.

* Inform IEC immediately in case of any Adverse events and Serious adverse event.
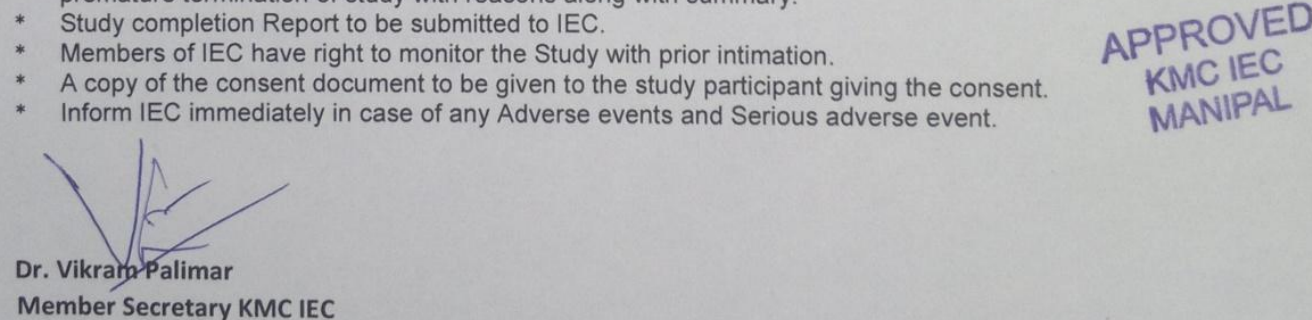